\title{
REPUTATION aS a Disciplinarian OF INTERNATIONAL OrganizaTIONS
}

\author{
By Kristina Daugirdas*
}

\section{ABSTRACT}

As a disciplinarian of international organizations, reputation has serious shortcomings. Even though international organizations have strong incentives to maintain a good reputation, reputational concerns will sometimes fail to spur preventive or corrective action. Organizations have multiple audiences, so efforts to preserve a "good" reputation may pull organizations in many different directions, and steps taken to preserve a good reputation will not always be salutary. Recent incidents of sexual violence by UN peacekeepers in the Central African Republic illustrate these points.

On April 29, 2015, The Guardian published an explosive story based on a leaked UN document. ${ }^{1}$ The document described allegations against French troops who had been deployed to the Central African Republic pursuant to a mandate established by the Security Council. According to the allegations, during the first half of 2014, French soldiers raped and sexually exploited boys as young as nine years old, in some cases in exchange for food and money. The United Nations' reaction, as described in the story, made things even worse: upon learning about the allegations, UN offices in Geneva did nothing. Frustrated by this inaction, one official, Anders Kompass, leaked the document to French authorities. His boss responded by subjecting Kompass to disciplinary proceedings for the leak.

These allegations of rape and sexual misconduct, together with the United Nations' seeming indifference, appeared to cause immense damage to the organization's reputation. Indeed, the secretary-general and numerous member states and UN officials have invoked the organization's reputation and the imperative to repair it. ${ }^{2}$ These concerns about the reputation

* Professor of Law, University of Michigan Law School, kdaugir@umich.edu. For excellent comments and helpful discussions, I thank Nicholas Bagley, Laurence Boisson de Chazournes, Kristen Boon, Andrew Clapham, Monica Hakimi, Don Herzog, Vic Khanna, Nico Krisch, Nina Mendelson, Julian Mortenson, Jide Nzelibe, Anne Peters, Steve Ratner; the current and former UN officials who spoke with me; workshop participants at the ASIL Midyear Meeting, the Graduate Institute in Geneva, and the University of Michigan; and the anonymous reviewers. For outstanding research assistance, I thank Adele Daniel, Madison Kavanaugh, Kate Powers, and Marissa Perry.

${ }^{1}$ Sandra Laville, UN Aid Worker Suspended for Leaking Report on Child Abuse by French Troops, GUARDIAN (Apr. 29, 2015), at https://www.theguardian.com/world/2015/apr/29/un-aid-worker-suspended-leaking-report-childabuse-french-troops-car.

${ }^{2}$ See, e.g. . Secretary-General's Remarks to the Security Council Meeting on Sexual Exploitation and Abuse (Mar. 10, 2016), at https://www.un.org/sg/en/content/sg/statement/2016-03-10/secretary-generals-remarkssecurity-council-meeting-sexual ("First of all, I would like to thank you for your initiative in organizing this very important subject, which has a lot to do with our reputation and of our work in the future."); UN SCOR, 71st Sess., 7642d mtg. at 7-8, 11, 18, 21, UN Doc. S/PV.7642 (Mar. 10, 2016) (statements from China, the United Kingdom, Malaysia, New Zealand, and the secretary-general); UN Press Release, Addressing Sexual Exploitation, Abuse Cases Involving Peacekeepers Requires Swift Accountability, Decisive 
seemed to motivate some concrete, visible steps to address the problem of sexual violence perpetrated by UN peacekeepers and other UN-affiliated individuals. For the first time, the Security Council adopted a resolution specifically addressing sexual abuse and exploitation; ${ }^{3}$ for the first time, the organization ejected an entire contingent of UN peacekeepers in response to such incidents; ${ }^{4}$ and for the first time, a high-level UN official lost his job for mishandling them. ${ }^{5}$ Less than a week into his term as the newly appointed secretary-general of the United Nations, António Guterres signaled his intentions to stay focused on the issue by establishing a new task force to overhaul the organization's approach to preventing and responding to sexual violence. ${ }^{6}$

In this instance, reputational concerns appeared to motivated some reforms. But if the reputational damage from such incidents is so extensive, and so predictable, why did the United Nations and its member states not do more to avoid it? The allegations brought to light in 2015 were by no means unprecedented. Indeed, journalists and nongovernmental organizations began calling attention to the problem of sexual violence by UN peacekeepers and others-and the organization's desultory response to such allegations-in the 1990s. ${ }^{7}$ Since then, public attention has periodically seized on allegations that, yet again, UN peacekeepers and others were victimizing the vulnerable individuals they were charged with protecting, and the United Nations was doing relatively little to ensure that the perpetrators were punished.

The very persistence of the problem over more than two decades suggests that reputational concerns were insufficient to discipline the United Nations. If so, why? The answer matters because, for international organizations, reputational sanctions are among the few constraints on abuse. ${ }^{8}$ Formal legal mechanisms are only rarely available. Immunity usually keeps injured individuals from being able to sue international organizations in national courts. ${ }^{9}$ The International Court of Justice is formally available to issue advisory opinions regarding international organizations, but doing so requires the UN General Assembly or another UN organ to adopt a resolution requesting one. Such requests are very rare.

Action, Speakers Tell General Assembly, UN Doc. GA/11819 (Sept. 7, 2016), at https://www.un.org/press/en/ 2016/ga11810.doc.htm (statements from Jordan, Sweden, Mexico, the United Kingdom, and China that addressed reputational harm to the United Nations).

3 SC Res. 2272 (Mar. 11, 2016).

${ }^{4}$ MINUSCA Press Release, New Allegations of Sexual Abuse Emerge Against MINUSCA Peacekeepers (Feb. 4, 2016), at https://minusca.unmissions.org/en/new-allegations-sexual-abuse-emerge-against-minuscapeacekeepers.

${ }^{5}$ UN's CAR Envoy Gaye Sacked Over Peacekeeper Abuse Claims, BBC (Aug. 12, 2015), at http://www.bbc.com/ news/world-africa-33890664.

${ }^{6}$ UN Press Release, Secretary-General Creates High-Level Task Force to Improve United Nations Approach for Preventing, Addressing Sexual Abuse, UN Doc. SG/A/1697 (Jan. 6, 2017).

${ }^{7}$ Guglielmo Verdirame, The United Nations and Human Rights: Who Guards the Guardians 215-18 (2011); Muna Ndulo, The United Nations Responses to the Sexual Abuse and Exploitation of Women and Girls by Peacekeepers During Peacekeeping Missions, 27 BerKeley J. INT'L L. 127, 141-46 (2009).

${ }^{8}$ See generally Ruth W. Grant \& Robert O. Keohane, Accountability and Abuses of Power in World Politics, 99 AM. Pol. SCI. REV. 29 (2005) (identifying and analyzing source of accountability of international organizations).

${ }^{9}$ While tort victims rarely have access to alternative remedies, individuals who have a contractual relationship with the organization do more often. For example, the employees of international organizations are usually able to turn to specialized administrative tribunals, and private individuals or firms that contract with international organizations may negotiate waivers that provide for dispute settlement. 
Outside of the context of international organizations, a large literature explores how reputational sanctions sometimes substitute for more formal legal sanctions. ${ }^{10}$ In general, the literature characterizes reputation as a positive force. For example, reputation features prominently in accounts of why states comply with international law. ${ }^{11}$ Reputation can also explain why corporations sometimes go above and beyond what the law requires, and take voluntary steps to protect the environment or promote robust labor standards in their global supply chains. ${ }^{12}$ Scholars of domestic administrative agencies, including local police departments, the Food and Drug Administration (FDA), and the Federal Reserve, have also explored ways that reputation serves as a powerful motivator-and, by extension, as a constraint on the behavior of actors within those agencies. ${ }^{13}$

Very little scholarship, by contrast, explores how reputational dynamics play out for international organizations. ${ }^{14}$ Building on the literature regarding other kinds of organizations and using recent developments related to sexual violence in the Central African Republic as a case study, this Article seeks to fill that gap. I argue that as a disciplinarian, reputation has some serious shortcomings. Sometimes reputational harm will fail to move an organization at all. Sometimes reputational harm will motivate changes - but only superficial ones. And sometimes concern about reputational harm will not only fail to solve the underlying problem, but also tempt organizations to cover it up.

Part I of this Article explains why maintaining a good reputation is more complicated than may appear. An international organization's reputation reflects the aggregate beliefs of its observers. ${ }^{15}$ But its reputation is multifaceted, not one-dimensional. International organizations (like domestic administrative agencies) have distinct reputations for legality, morality,

${ }^{10}$ For an earlier example, see Stewart Macaulay, Non-contractual Relations in Business: A Preliminary Study (1963), 28 Am. Soc. Rev. 55 (1963); Robert Ellickson, Order Without LaW (1991); see also infra note 23.

${ }^{11}$ Andrew T. Guzman, How International LaW Works 33-41, 71-117 (2008); Rachel Brewster, Unpacking the State's Reputation, 50 Harv. Int'l L.J. 231 (2009); Robert E. Scott \& Paul B. Stephan, The Limits of Leviathan: Contract Theory and the Enforcement of International Law (2006); Beth Simmons, International Law and State Behavior: Commitment and Compliance in International Monetary Affairs, 94 AM. Pol. SCI. Rev. 819 (2000)

12 See, e.g., David Vogel, The Market for Virtue (2005). Indeed, regulations that require information disclosure on such topics are designed to operate by raising the reputational stakes. See Adam S. Chilton \& Galit A. Sarfaty, The Limitations of Supply Chain Disclosure Regimes, 57 STAN. J. InT'L L. 1 (2017); James T. Hamilton, Regulation Through Revelation: The Origin, Politics, and Impacts of the Toxics Release Inventory Program (2005).

${ }^{13}$ Daniel Carpenter, Reputation and Power: Organizational Image and Pharmaceutical Regulation at the FDA (2010); Charles R. Epp, Making Rights Real: Activists, Bureaucrats, and the Creation of the Legalistic STATE (2009) (concluding that lawsuits prompted U.S. police departments to revise their policies on use of force and handling claims of abuse not because the lawsuits imposed financial costs, but because they threatened the defendants' professional reputations); Kathryn Judge, The Federal Reserve: A Study in Soft Constraints, 78 L. \& Contemp. Probs. 65 (2015); Nicholas R. Parrillo, The Endgame of Administrative Law: Governmental Disobedience and the Judicial Contempt Power, 131 Harv. L. REv. 685 (2018); Emily Chiang, Institutional Reform Shaming, 120 PENN ST. L. REv. 53 (2015)

${ }^{14}$ For an important exception, see Ian Johnstone, Do International Organizations Have Reputations?, 7 INT'L ORGs. L. Rev. 235, 239 (2010). Some of my own work has explored reputation in connection with the introduction of cholera to Haiti by UN peacekeepers. See Kristina Daugirdas, Reputation and the Responsibility of International Organizations, 25 Eur. J. INT'L L. 991, 1013 (2014) [hereinafter Daugirdas 2014]; Kristina Daugirdas, Reputation and Accountability: Another Look at the United Nations' Response to the Cholera Epidemic in Haiti, _ INT'L ORgs. L. REv. ___ (forthcoming 2019) (applying the framework set out in this Article) [hereinafter Daugirdas 2019].

${ }^{15}$ Carpenter, supra note 13 , at $18,26$. 
effectiveness, and expertise. International organizations also have reputations for being independent from-or responsive to-their member states, or particular subsets of member states. In general, tensions among these different dimensions are common, and some trade-offs are unavoidable. In addition to having multiple reputations, international organizations have multiple audiences, including government officials and the general public. These different audiences do not always train their attention on the same feature of the organization's conduct, or evaluate what they see according to the same criteria. Keeping these multiplicities in mind, Part II then considers some of the ways that international organizations might respond to threats to their reputation, not all of which will be positive.

To illustrate and deepen this account of how reputation works for international organizations, Part III focuses on the Central African Republic. Notably, in the months after The Guardian article described above was published, it became clear that the allegations against the French soldiers reflected only a small part of a bigger problem. Many more allegations subsequently came to light against "blue helmets"-peacekeepers under UN commandin the Central African Republic. In turn, these new allegations called attention to a questionable decision the UN Secretariat made to accept peacekeeping troops from the Democratic Republic of the Congo (DRC) notwithstanding their inclusion on the United Nations' own list of parties that engage in sexual violence against children. The reputational account set out in Part I helps to explain this and other key decisions made by UN officials before and after the allegations against the French soldiers were revealed to the public.

The absence of clear rules defining an organization's legal obligations compounds the problem. The United Nations, for example, has no clear legal obligations to prevent or respond to allegations of sexual violence. As a result, one particularly important dimension of the United Nations' reputation - its reputation for compliance with the law-was not on the line in the Central African Republic. In general, reputation will be a less effective disciplinarian for lawbreaking where there is room for debate over whether a particular act or omission is legal or illegal. That sort of uncertainty is endemic to international organizations: their legal obligations are often contested and, as noted above, courts are rarely available to clarify them.

Even when reputational concerns do motivate organizations to respond to or prevent reputational harm, there is the question of how organizations respond. One possibility is that organizations will limit themselves to symbolic or superficial steps designed to quell the immediate furor without solving the underlying problem. Organizations might opt for this approach if they care more about the image they project than about whether that image corresponds to reality. ${ }^{16}$ They might also take this approach if they recognize the need to respond but cannot muster the political will to take more forceful measures. Either way, it should not be surprising when symbolic measures prove ineffective.

Another troubling possibility is that organizations will try to protect their reputations by concealing derogatory information. After all, so long as derogatory information stays hidden, it cannot cause reputational harm. International organizations have significant tools at their disposal to control and to limit the release of information about their activities. Indeed, the director of an NGO quoted in The Guardian story described above characterized the United

\footnotetext{
${ }^{16}$ Some NGOs have suggested as much. See, e.g., Bea Edwards, How to End Sexual Abuse in UN Peacekeeping Missions, Gov't Accountability Project (May 31, 2016), available at https://www.whistleblower.org/uncategorized/how-to-end-sexual-abuse-in-un-peacekeeping-missions.
} 
Nations' initial response to the allegations as both "stomach turning" and consistent with the organization's “instinctive response to sexual violence in its ranks-ignore, deny, cover up, [and] dissemble."17

Part IV briefly turns to some of the policy implications of the Article's account of how reputation works for international organizations. Specifically, it argues that reputation can be a more effective disciplinarian if pathological strategies for coping with reputational threats are made both less available and less attractive. This Part offers a warning: simply making reputation a more prominent organizational concern may well backfire. That said, a sophisticated understanding of reputational dynamics can usefully inform policy design, as well as highlight the advantages and risks of some of the steps that the United Nations adopted after events in the Central African Republic came to light.

\section{Reputation and its Multiplicities}

To set out a framework for understanding reputational dynamics regarding international organizations, this Article draws on the reputational literature relating to other kinds of organizations and entities: private firms, nongovernmental organizations (NGOs), administrative agencies, and states. International organizations have important commonalities with-as well as some salient differences from-these other kinds of organizations.

At bottom, a reputation is a set of beliefs that observers hold, or judgments that observers make, about an individual or an organization. ${ }^{18}$ A good reputation is a source of value. For private firms, that value can be measured in dollars and cents. ${ }^{19}$ Administrative agencies with good reputations will attract more resources and more responsibilities. ${ }^{20}$ A good reputation is what allows nongovernmental organizations to be effective and influential notwithstanding their lack of coercive powers and (relative) lack of financial resources. ${ }^{21}$ For states, too, a good reputation is a source of soft power-that is, of influence above and beyond their material resources. ${ }^{22}$ Because good reputations are valuable, the desire to maintain a good reputation can be a powerful motivator. The reverse is also true: a bad reputation is a source of costs along all of these dimensions. For this reason, reputation can be a disciplining force, a source of penalties when an organization (or individual or other entity) falls short. ${ }^{23}$

These penalties_-often termed reputational costs_-are an informal, nonlegal sanction. Reputational costs are not coordinated and centralized; instead they are imposed directly

${ }^{17}$ Laville, supra note 1.

${ }^{18}$ CARPENTER, supra note 13, at 33 ("Reputations are composed of symbolic beliefs about an organization-its capacities, intentions, history, mission — and these images are embedded in a network of multiple audiences.").

${ }^{19}$ David Charney, Nonlegal Sanctions in Commercial Relationships, 104 Harv. L. Rev. 373, 396-97 (1990) (noting, for example, that firms with good reputations can charge higher prices for its products—or attract workers while paying lower wages).

${ }^{20}$ CARPENTER, supra note 13 , at 26, 54 .

${ }^{21}$ Paul Wapner, Defending Accountability in NGOs, 3 CHI. J. INT'L L. 197, 203 (2002).

22 Joseph S. Nye, Jr., Soft Power (2004).

${ }^{23}$ There is a large law-and-economics literature that explores reputation as a type of informal sanction and considers, among other things, whether legal penalties ought to be adjusted to account for nonlegal sanctions including reputational sanctions. See, e.g., Edward M. Iacobucci, On the Interaction Between Legal and Reputational Sanctions, 43 J. Legal STUd. 189 (2014); Murat C. Mungan, A Generalized Model for Reputational Sanctions and the (Ir)relevance of the Interactions between Legal and Reputational Sanctions, 46 INT'L REV. L. \& ECON. 86 (2016); V.S. Khanna, Corporate Criminal Liability: What Purpose Does It Serve?, 109 Harv. L. Rev. 1477 (1996). 
by those who observe or interact with a particular organization. When an organization's reputation is damaged - that is, when an organization's audience discovers that the organization is worse than previously believed along some dimension, the organization's audience will change its behavior. Some members of the audience may choose to stop interacting with the organization entirely, or they may drive a harder bargain when they do. Thus, for example, a state that develops a reputation for not living up to its treaty commitments will have a harder time finding treaty partners, and a firm that develops a reputation for making lousy products will have fewer repeat customers.

To understand when and how reputational concerns will affect organizational decisionmaking, it is essential to keep in mind three multiplicities: (1) the multiplicity of reputations that these individuals and entities can have; (2) the multiplicity of audiences who observe and judge those individuals and entities; and (3) the multiplicity of individuals and entities within an organization to whom or to which a reputation can attach. These multiplicities explain why organizations that may appear unmoved by reputation costs are actually quite sensitive to them. In other words, it is not that international organizations are indifferent to reputational costs, but that they face trade-offs among different facets of reputation and sometimes cannot simultaneously satisfy the diverging preferences of their multiple audiences.

\section{A. IO Reputation Matters}

To start, it is worth elaborating why having a good reputation is especially important to international organizations. International organizations are like nongovernmental organizations in that their material resources are quite limited; so too are their formal legal authorities. As a result, their effectiveness turns to a significant degree on their ability to persuade other actors to take or refrain from a particular course of action. And their capacity to persuade depends on having a good reputation. ${ }^{24}$ A good reputation makes it more likely that these organizations will be taken at their word. Thus, for example, the reputation of the Organization for Economic Co-operation and Development (OECD) is so good among scholars that they will often cite OECD statistics without feeling any need to justify them as a valid measure of the indicator in question. ${ }^{25}$ Also like nongovernmental organizations, international organizations compete for resources. They must be able to make a convincing case that their cause is a worthy one-and that they can make some headway in addressing it. After all, states could choose to devote their resources elsewhere-to other international organizations or initiatives, or even to national government agencies.

Among other things, international organizations' dependence on voluntary cooperation and support narrows the kinds of reputations they might cultivate. While some states might prefer to chart an isolationist and belligerent course of action, international organizations do not have that option. Some private firms — think Uber-develop business models that involve deliberately flouting certain laws or regulations that apply to their conduct. ${ }^{26}$

\footnotetext{
${ }^{24}$ J.C. Sharman, Rationalist and Constructivist Perspectives on Reputation, 55 POL. STUD. 20, 30 (2007) (arguing that "[a]n international organization's effectiveness is inseparably bound up with judgments about the reputation of that institution").

${ }^{25} I d$. at 31 (quoting Tony Porter and Michael Webb).

${ }^{26}$ Elizabeth Pollman \& Jordan Barry, Regulatory Entrepreneurship, 90 So. CAL. L. Rev. 383 (2017) (describing certain private firms, including Uber, making decisions to strategically violate applicable laws and regulations as part of their business model).
} 
It is hard to see an international organization pursuing a comparable strategy by, say, ignoring obligations undertaken in a headquarters agreement in order to pressure a host state. ${ }^{27}$

It is quite common for high-level officials to describe preserving a good reputation for their organization as a central aspect of their jobs. Thus, in a vision statement he submitted as a candidate for the post of secretary-general, António Guterres wrote: "The SG must stand firmly for the reputation of the UN and its dedicated staff." 28 A scholar describing the work of the Global Water Partnership wrote: "There is constant attention paid to the reputational risks induced by each and every action which can be described as part of the activity of GWP." ${ }^{29}$ Member states have also expressed concern about the reputations of the organizations in which they participate. This is the case with respect to sexual exploitation and abuse by UN peacekeepers and others implementing UN mandates. ${ }^{30}$ And it is also true more generally. ${ }^{31}$

Some international organizations have adopted policies that explicitly instruct staff to consider the consequences of their actions for the reputation of the organization that employs them. For example, the word "reputation" appears eighteen times in the World Health Organization's Code of Ethics and Professional Conduct. ${ }^{32}$ Action that results in reputational

\footnotetext{
${ }^{27}$ Given the uncertainty and contestation regarding many aspects of international organizations' international legal obligations, international organizations do sometimes operate in "gray areas" where the content of their obligations is not clear. See infra Part III.E. In these situations, international organizations use a range of strategies to avoid being perceived as scofflaws. Sometimes they will comply with the relevant norm without expressly acknowledging any legal obligation to do so; sometimes they will cease the challenged conduct; and sometimes they will directly challenge the applicability of the relevant norm. See Daugirdas 2014, supra note 14, at 1012-16.

${ }^{28}$ Jenni Lee, 7 Quotes from António Guterres, UN Found. BLOG (Oct. 11, 2016), at http://unfoundationblog. org/7-quotes-from-antonio-guterres.

${ }^{29}$ Edouard Fromageau, The Global Water Partnership: Between Institutional Flexibility and Legal Legitimacy, 8 INT'L ORGs. L. Rev. 367, 393-94 (2011).

${ }^{30}$ See supra note 2; see also Kieran Guilbert, UN Investigating Leaked Sex Abuse Complaints in Central African Republic, Reuters (Sept. 14, 2017), at https://www.reuters.com/article/us-centralafrica-un-peacekeepers/uninvestigating-leaked-sex-abuse-complaints-in-central-african-republic-idUSKCN1BP2QC (quoting MINUSCA spokesperson Vladimir Monteiro as saying: "It [MINUSCA] recognizes that sexual exploitation and abuse cases have severely affected the mission's credibility and reputation in the past."); UN SC, 6942nd mtg., UN Doc. S/PV.6842 at 5 (Oct. 3, 2012) ("The Secretary-General has recalled that the first priority is the reputation of the United Nations. It is for that reason, inter alia, that in Haiti we have intensified our zero-tolerance measures against abuse of all kinds, especially the sexual abuse of minors.") (statement of the Head of the United Nations Stabilization Mission in Haiti); UN SC, 6936th mtg., UN Doc. S/PV.6936 at 4 (Mar. 20, 2013) ("It is essential to our reputation that the conduct of our personnel be in conformity with the highest standards and that prompt and decisive action be taken to prevent abuse, to investigate allegations and to impose disciplinary measures where warranted.") (statement of interim head of the United Nations Stabilization Mission in Haiti); UN Will Enforce "Zero Tolerance" Policy Against Sexual Abuse, Peacekeeping Official Says, UN News (Jan. 5, 2007), at https://news.un.org/en/story/2007/01/205142-un-will-enforce-zero-tolerance-policy-against-sexual-abusepeacekeeping (quoting Assistant Secretary-General Jane Holl Lute as saying: "The reputation of UN peacekeeping is one of our most powerful assets, which is why we have responded over the past couple of years so strongly[.]").

31 See, e.g., Johnstone, supra note 14, at 238; Ian Hurd, The Strategic Use of Liberal Internationalism 59 INT'L ORG. 495 (2005); Daugirdas 2014, supra note 14.

${ }^{32}$ World Health Organization, Code of Ethics and Professional Conduct (Apr. 9, 2017), available at http://www. who.int/about/ethics/code_of_ethics_full_version.pdf; see also, e.g., International Monetary Fund (IMF), Code of Conduct for Staff(July 31, 1998), at https://www.imf.org/external/hrd/code.htm ("We all have a responsibility to contribute to the good governance of the IMF and to help maintain its reputation for probity, integrity, and impartiality."); see also id. ("You should refrain from participating in any activity that is in conflict with the interests of the IMF or would damage the IMF's reputation."); World Intellectual Property Organization, Code of Conduct, Including Procurement Related, for WIPO Staff, available at http://world-intellectual-property-organization.com/ export/sites/www/procurement/en/docs/code_of_conduct_for_wipo_staff_including_procurement.pdf ("The
} 
damage to the United Nations can qualify as an abuse of authority by senior UN personnel. ${ }^{33}$ Of particular relevance to the Central African Republic case study, UN peacekeepers have been required since 2017 to carry a "No Excuse" pocket card; among other things, the card reminds peacekeepers: "Sexual exploitation and abuse undermines discipline, and damages the reputation of the United Nations." 34 Given the importance of reputation to international organizations' efficacy, such deliberate efforts are unsurprising.

\section{B. Three Multiplicities}

So far, this discussion has discussed reputations as ranging from good to bad along a onedimensional spectrum. In fact, reputation and reputational dynamics are more complicated.

\section{Multiplicity of reputations}

The first complication is that reputations are multi-dimensional. A person might simultaneously have reputations for being a brilliant lawyer and a jerk. ${ }^{35}$ In the international realm, in addition to having reputations for complying with the law (or not), states also have reputations for cooperativeness, rationality, and toughness. ${ }^{36}$ Private corporations have, in addition to reputations for legality, reputations for the quality of their products or customer service, reputations as employers, and reputations for their corporate citizenship. Domestic administrative agencies have reputations for efficacy (that is, for the quality of their decision making and their capacity for effectively achieving their objectives), as well as for technical expertise, morality, and legality. ${ }^{37}$

The reputations of international organizations are similarly multifaceted. To a significant degree, the salient dimensions of IO secretariats' reputations track those of domestic administrative agencies. International organizations too have reputations for efficacy, morality, legality, and technical expertise.

In addition, international organizations have a fifth salient dimension of reputation: they have reputations for independence from, or responsiveness to and cooperativeness with, their member states (or subsets of their member states). These elements of secretariats' reputations are especially important, and also in some tension with one another. On the one hand,

staff member should at all time behave in a way that upholds the values and the integrity and good reputation of WIPO.”).

${ }^{33}$ Marie Deschamps, Hassan B. Jallow \& Yasmin Sooka, Report of an Independent Review on Sexual Exploitation and Abuse by International Peacekeeping Forces in the Central African Republic, Taking Action on Sexual Exploitation and Abuse by Peacekeepers, at 67, 75, UN Doc. A/71/99 (Dec. 17, 2015), at https://digitallibrary.un.org/record/840749/?ln=en [hereinafter CAR Panel Report].

${ }^{34}$ UN Press Release, The "No Excuse" Card Is Online and Ready to be Distributed (June 2, 2017), at https:// www.un.int/news/no-excuse-card-online-and-ready-be-distributed.

${ }^{35}$ Indeed, even focusing just on professional reputation, it is possible to break out additional dimensions. See, e.g., Jack Goldsmith, Lawyerly Integrity in the Trump Administration, LaWfare (May 14, 2017), at https://www. lawfareblog.com/lawyerly-integrity-trump-administration (noting that political appointees in government have, inter alia, reputations for loyalty, competence, and the quality of their judgment).

${ }^{36}$ Brewster, supra note 11; Jack L. Goldsmith \& Eric A. Posner, The Limits of International Law 102-03 (2007), Robert O. Keohane, International Relations and International Law: Two Optics, 38 Harv. INT'L L. J. 487, 497 (1997); Ryan Brutger \& Joshua T. Kertzer, A Dispositional Theory of Reputation Costs, 72 INT'L OrG. 693,699 (2018); George W. Downs \& Michael A. Jones, Reputation, Compliance, and International Law, 31 J. LEGAL STUD. S95 (2002).

37 CARPENTER, supra note 13 , at 46-47. 
international organizations have strong incentives to be cooperative with their member states. ${ }^{38}$ After all, they are the ones who created the organization-and they are the ones who fund and otherwise sustain the organization's activities. On the other hand, international organizations are often effective and influential precisely because their secretariats are perceived to be independent and not in the pocket of any individual state or group of states. In other words, independence is an essential component of their authority and effectiveness. ${ }^{39}$ For example, independence is what makes states willing to negotiate with or accept advice or conditions from international organizations that they would reject from other states on the grounds that advice coming from other governments is biased or strategically motivated. ${ }^{40}$

Tensions among different facets of reputation are common. Thus, for example, Nick Parrillo describes the administrator of the Environmental Protection Agency being torn between promulgating environmental standards within statutorily required deadlines and ensuring those standards have adequate scientific support—something that takes time to develop. ${ }^{41}$ As a result, organizations cannot always avoid reputational costs altogether, though they may be able to choose where the blows land.

\section{Multiplicity of audiences}

The second multiplicity that is crucial to understanding reputational dynamics concerns audience or audiences. As noted above, an organization's audience is made up of all of the individuals and entities that are in a position to observe, evaluate, and judge an organization's actions - and to impose reputational costs in response to undesirable behavior. For corporations, these audiences include consumers, shareholders, employees, regulators, and banks. ${ }^{42}$ For administrative agencies, like the FDA, the audiences include scientists, the U.S. Congress, consumer representatives, and media organizations. ${ }^{43}$ For international organizations, these observers - their audience-include not just member states, but also academics, journalists, nongovernmental organizations, and government officials like judges and members of legislatures.

The public is an important audience too-including, perhaps counterintuitively, for international organizations. The ability to speak "over the heads" of governments and directly address the public is an important source of these organizations' authority and influence. ${ }^{44}$ International organizations make deliberate efforts to reach the public through speeches, op-

\footnotetext{
${ }^{38}$ Paul B. Stephan, Reputation and Responsibility: Moving the Goalposts, EJIL: TALK! (Mar. 26, 2015), at https:// www.ejiltalk.org/reputation-and-responsibility-moving-the-goalposts; see also SCOTT \& STEPHAN, supra note 11.

${ }^{39}$ Michael Barnett \& Liv Coleman, Designing Police: Interpol and the Study of Change in International Organizations, 49 INT'L STUD. Q. 593, 598 (2005) (international organizations' claims to authority "frequently turn on the belief that they are impersonal and neutral, that is, that they are not exercising power but instead are using impartial, objective, and value-neutral knowledge to serve others. . . . Because their authority is premised on these beliefs, international organizations are likely to be quite attentive to this very image ...").

${ }^{40}$ For a theoretical account of the value of independence, see Kenneth W. Abbott \& Duncan Snidal, Why States Act Through Formal International Organizations, 42 J. Conflict Res. 3 (1998). For a narrative account of the value of the independence of the UN secretary-general, see Brian URQUHART, HaMMARSKJOLD 94-105 (1972).

${ }^{41}$ Parrillo, supra note 13, at 791-93.

${ }^{42}$ Cf. Gary Alan Fine, Difficult Reputations 167-68 (2001) (identifying consumers, shareholders, employees, fellow business leaders, and the general public as judges of economic figures).

${ }^{43}$ Carpenter, supra note 13 , at 10.

44 Thomas M. Franck, Nation Against Nation 121 (1985).
} 
eds, and - these days — social media. ${ }^{45}$ These efforts often bear fruit: the public often accords significant weight to the recommendations and decisions of international organizations. ${ }^{46}$ The particular communities in which international organizations operate constitute another public audience for the organization. The organization's reputation in the eyes of these communities can have direct impacts on the success or failure of an operation on the ground. ${ }^{47}$

Several observations can be made about these various audiences. First, the audiences are not merely passive recipients of information supplied by the organization they are observing. ${ }^{48}$ These audiences can contribute new legal arguments, facts, or factual analysis, and they can evaluate the legal and factual analysis done by others. ${ }^{49}$ Sometimes they can take actions that can lead to formal legal sanctions. For example, in the United States, an NGO could file a citizen suit alleging that a certain corporation is violating the Clean Water Act. Such audience members can also keep an issue in the public eye long after the targeted entity hoped attention would fade. ${ }^{50}$

Second, an organization's audiences may reach divergent conclusions when evaluating its conduct. These may focus their attention on different information. A corporation's shareholders might be most concerned about a firm's profitability, while a human rights NGO might be most concerned about the labor conditions in the firm's supply chain. Even when they are observing identical conduct, audience members may evaluate it differently, disagreeing about the importance of a particular incident, and even whether that incident reflects well or poorly on the actor. ${ }^{51}$ When the FDA takes a tough enforcement action, consumers may cheer the same decision that pharmaceutical companies deplore. Ideology and

\footnotetext{
${ }^{45}$ Ana Campoy, These Are the Most Popular International Organizations on Twitter, QUARTZ (Nov. 30, 2017), at https://qz.com/1143475/the-un-is-the-international-organization-with-the-most-followers-on-twitter (noting that the United Nations had 9.4 million Twitter followers in 2017 and that other international organizations likewise had millions); António Guterres, Opinion, The Rohingya are Victims of Ethnic Cleansing. The World Has Failed Them. WASH. POST. (July 10, 2018), at https:/www.washingtonpost.com/opinions/the-rohingya-are-victims-of-ethniccleansing-the-world-has-failed-them/2018/07/10/08cab8a0-8447-11e8-9e80-403a221946a7_story.html.

46 See generally Katerina Linos, The Democratic Foundations of Policy Diffusion (2013); see also Alexander Thompson, Screening Power: International Organizations as Informative Agents, in DELEGATION AND Agency in International Organizations 229 (Darren G. Hawkins, David A. Lake, Daniel L. Nielson \& Michael J. Tierney eds., 2006).

47 See Daugirdas 2019, supra note 14 (discussing the United Nations' concerns about its reputation on the ground in Haiti).

${ }^{48}$ Capturing this idea, Gary Alan Fine uses the term "reputational entrepreneurs" to describe these audiences with varying resources, outlets, and interests when it comes to observing and making claims about the target. FINE, supra note 42, at 20-21 (2001); see also id. at 63 (explaining that reputational entrepreneurship "depends upon the presence of three elements: motivation, narrative facility, and institutional placement"); $i d$. at 87 (identifying features that are critical to the success of reputational entrepreneurs: "the interests of a community, the narrative resonance of the reputation, and the institutional placement of those making claims").

${ }^{49}$ Daugirdas 2014, supra note 14, at 998-99. Audiences can also help shape reputation by remaining silent, and thereby ceding ground to others. FINE, supra note 42, at 60-90 (explaining how President Warren Harding's reputation for incompetence solidified in part due to the silence of those who could have supplied and supported a rival narrative).

${ }^{50}$ Daugirdas 2014, supra note 14, at 1000-07.

51 See Brutger \& Kertzer, supra note 36 (using survey data to illustrate that individuals with different policy dispositions (i.e., hawks and doves) disagree about whether certain actions related to foreign policy enhance or damage reputation).
} 
partisanship may also underlie divergent assessments of the same conduct. ${ }^{52}$ In short, in the face of heterogenous audiences, defining a "good" reputation is no mean task. ${ }^{53}$

Third, and most importantly, organizations are not equally responsive to all of their audiences. The reputational literature on private firms is especially useful for this point. Sometimes a negative evaluation will prompt an organization to change because market transactions internalize the cost. Thus, private firms that defraud customers will not have much repeat business, and companies that defraud their employees will face higher input costs. ${ }^{54}$ But what about when firms harm individuals with whom they do not do business? Consider an electroplating company that dumps toxic chemicals into a municipal storm sewer, thereby damaging downstream fisheries. ${ }^{55}$ If the firm is acting illegally, it will face legal costs from the violation. But it may not face reputational costs above and beyond those legal costs. The fishermen do not do business with the firm; those who do lack incentives to reduce their demand for the firm's product, since the dumping does not affect the product's quality. ${ }^{56} \mathrm{And}$, indeed, some empirical evidence supports the conclusion that firms that violate environmental laws do not face reputational penalties that exceed the legal penalty. ${ }^{57}$

This example highlights one feature of reputation that distinguishes it from formal mechanisms of accountability: organizations do not have an obligation to respond to any and all press stories, academic articles, or reports by NGOs that may damage their reputations. ${ }^{58}$ And there are instances where organizations may rationally choose to "ride out" reputational damage and not change their practices. For example, a firm that is getting bad press about the labor practices in its supply chain may choose to ignore that media coverage if its shareholders remain happy. 59

While the public's attention may be short-lived or sporadic, for international organizations, member states are an especially important audience. International organizations' governance mechanisms assure that member states will continue to pay attention to the organization for the long term. Of course, these member states will not always agree or act in concert. ${ }^{60}$ Especially when member states disagree, international civil servants will have to make choices about which states to heed. These officials may have particularly strong incentives to be responsive to particular states or subsets of states-especially those states that

52 See, e.g., infra note 289.

${ }^{53}$ For a formal model demonstrating this point for private firms, see Heski Bar-Isaac \& Joyce Deb, What Is a Good Reputation? Career Concerns with Heterogeneous Audiences, 34 InT'L J. Indus. Org. 44 (2014). See also Fine, supra note 42, at 170, 189 (identifying strategies for managing the predicaments created by multiple audiences).

54 Jonathan M. Karpoff, John R. Lott \& Eric W. Wehrly, The Reputational Penalties for Environmental Violations: Empirical Evidence, 48 J. L. \& ECON. 653, 655 (2005).

${ }^{55} I d$. at $656-66$.

${ }^{56} \mathrm{Id}$.

57 Id. at 668 .

58 Richard B. Stewart, Remedying Disregard in Global Regulatory Governance, 108 AJIL 211, 253-54 (2014) (rejecting the view that reputation is an accountability mechanism because, in his view, accountability mechanisms all involve a right to demand an accounting and to invoke a remedy, and an obligation on the part of the organization to render an account); Devika Hovell, Due Process in the United Nations, 110 AJIL 1, 45 (2016) (pointing out that reputation costs do not ensure responsiveness on the part of the United Nations).

${ }^{59}$ Vogel, supra note 12, at 70-71, 77-82 (describing Nike's shifting responses to criticisms of its labor practices by NGOs and the press).

60 See infra text accompanying notes 80-83 (describing some competing priorities that influence the positions and decisions that states take with respect to international organizations). 
supply key resources to the organization. ${ }^{61}$ These states are in positions rather like a private firm's big shareholders. The resources they supply include, most obviously, funding. But there are other kinds of resources too. For the United Nations, peacekeepers are another resource that is constantly in high demand. ${ }^{62}$ Put in terms of reputation, the states that provide such resources are likely to be an especially important audience of international organizations.

In some cases too, member states are in a position akin to the customers of an international organization. For example, the World Bank lends to middle-income countries on terms that are slightly better than what is available on the private market. The interest that these countries pay on their loans is an important source of funding for the Bank's operations, and makes the Bank less dependent on its member states. ${ }^{63}$ At the same time, these countries have access to private-sector loans as well. If dealing with the Bank is unattractive, they have the option to turn elsewhere. As a result, the Bank is quite careful to maintain its appeal to these borrowing states. ${ }^{64}$

By contrast, those member states that desperately need services and assistance from international organizations may be a less important audience. These states may need to maintain a good relationship with the organizations even more than the organizations need to maintain a good relationship with them. Thus, for example, as evidence started mounting that UN peacekeepers were the source of the 2010 cholera outbreak in Haiti, the Haitian government went out of its way to protect and shield the United Nations, and generally refrained from making strong demands on the organization to provide recourse to Haitian victims. ${ }^{65}$

It is also important to remember that an organization's audiences are not hermetically sealed from one another. Reconsider the example of the firm whose labor practices are the target of NGO and media criticism. The general public may include many actual and potential consumers of that corporation's product. If those consumers change their purchasing decisions, then the shareholders will see an effect. ${ }^{66}$ By extension, when an international organization's reputation in the general public suffers, government officials may become less willing to support the organization financially and otherwise, less willing to follow its recommendations, or more reluctant to turn to the organization to address new problems - preferring to work through other international organizations or forums, or perhaps through domestic agencies instead. ${ }^{67}$

${ }^{61}$ In addition, individual officials may be inclined to be responsive to the views of their states of nationality. See infra note 72 .

${ }^{62}$ See, e.g., Ban Ki-moon, Cyril Foster Lecture, University of Oxford: "Human Protection and the 21st Century United Nations" (Feb. 2, 2011), available at https:/www.un.org/sg/en/content/sg/speeches/2011-02-02/cyrilfoster-lecture-oxford-university-human-protection-and-21st ("Securing the required resources and [peacekeeping] troops has consumed much of my energy. I have been begging leaders to make resources available to us.").

${ }^{63}$ Kristina Daugirdas, Congress Underestimated: The Case of the World Bank, 107 AJIL 517 (2013).

64 See generally Catherine Weaver, Hypocrisy Trap (2008) (describing this dynamic).

${ }^{65}$ Daugirdas 2014, supra note 14, at 1002 (describing NGOs making demands that the Haitian government was unable or unwilling to make); Daugirdas 2019, supra note 14.

${ }^{66}$ VoGEL, supra note 12 at 47-56, 73-74.

${ }^{67}$ Cf. CARPENTER, supra note 13, at 54 ("As a general hypothesis, we may venture the statement that when all things are considered, the more legitimate, expert, and effective a regulator is perceived to be, the more likely politicians will be to create new regulations in policy areas that the regulator governs, and the more likely politicians will be to vest significant authority and resources in the regulator."). 


\section{Multiplicity of individuals and entities with reputations}

There is one last multiplicity that complicates reputational dynamics. The discussion so far has treated international organizations as unitary and discrete entities. In reality, they are neither. ${ }^{68}$ Organizations are made up of individuals, and those individuals have reputations and interests that are, to varying degrees, distinct from those of the institution itself. ${ }^{69}$ Individuals often identify, at least to some degree, with the organizations for which they work. ${ }^{70}$ Their identification may motivate them to seek to protect the organization's reputation. ${ }^{71}$ At the same time, individuals who work for an organization have their own separate reputations to protect, even when doing so comes at the organization's expense. ${ }^{72}$

Going still further, organizations are often divided into units and subunits. Reputations may attach to those nested units in addition to attaching to individuals within them. Consider the FDA. Reputations can and do attach to the scientists who work for the FDA, the FDA's enforcement division, the FDA itself, the executive branch of the government (or the administration of a particular president), and the federal government in its entirety (the "Feds"). For the United Nations, reputations can attach to individual offices, programs, or organs (such as the Office of the High Commissioner for Refugees, or the UN Security Council), to the UN Secretariat as whole, to the organization as defined by the UN Charter, and to the entire UN System, which includes the specialized agencies and other related organizations as well as the United Nations itself. ${ }^{73}$

Reputation, thus, can simultaneously attach to multiple individuals and entities that make up an organization, and sometimes to entities that extend beyond the formal legal boundaries of the organization. This feature of reputation is important because these individuals and entities may disagree about the amount of weight or significance to accord to any particular dimension of reputation - and may disagree about how much weight to put on the actual or anticipated response of any particular audience member.

Sometimes actors seek to take advantage of the multiple possibilities for locating the boundary lines around an organization. ${ }^{74}$ They might strategically push the salient boundary line

${ }^{68} \mathrm{Id}$. at 50.

${ }^{69}$ Johnstone, supra note 14, at 237 ("The Managing Director of the IMF and President of the World Bank have reputations to uphold, but their reputations are not coterminous with those of the organizations.”).

${ }^{70}$ CARPENTER, supra note 13, at 43, 47-51 (observing that the idea that human beings are motivated by esteem is long held - and that "the identity and esteem of an individual often depend upon wider social evaluations of the organization to which she belongs").

${ }^{71} I d$. at 48-49 (citing psychological literature that "under conditions of a public threat to an organization's identity - a scandal or an observable episode of poor performance-less attached members may exit the organization, whereas more attached members may exhibit a combination of defensive and corrective behavior"). See also Albert O. Hirschmann, Exit, Voice, and Loyalty (1970) (exploring responses by individuals to "repairable lapses" by various kinds of organizations).

${ }^{72}$ For example, individual IO officials may be particularly eager to cultivate reputations for responsiveness to their governments of nationality, perhaps because they are thinking about future job prospects within foreign ministries. See Jacob Katz Cogan, Representation and Power in International Organization: The Operational Constitution and Its Critics, 103 AJIL 209, 231 (2009) (quoting a former UN under-secretary general for writing: "A senior UN official nominated by his or her government was . . . assumed to be in the Secretariat to do that government's bidding . . . ."); FranCK, supra note 44, at 94-116.

73 The United Nations System, available at http://www.un.org/en/pdfs/18-00159e_un_system_chart_17x11_4c_en_web.pdf.

${ }^{7 \overline{4}}$ CARPENTER, supra note 13 , at 51. 
further out in order to claim credit. For example, President Clinton, facing a hostile Republican Congress for most of his presidency, deliberately sought to establish personal ownership over the regulatory activity of executive branch agencies. ${ }^{75}$ In other words, he sought to extend the relevant reputational boundary beyond the White House and to inscribe key administrative agencies within it. On the flip side, corporations presented with information about harsh labor practices among their suppliers may seek to disavow responsibility, seeking to shift blame by drawing the relevant boundary closer in. Nike initially took that approach in response to a news story broadcast on CBS in 1993 describing how workers in Indonesia were paid nineteen cents per hour and permitted to leave the company barracks only on Sundays. ${ }^{76}$

In focusing on "the United Nations," this Article draws the boundary line around the UN Secretariat, focusing on the secretary-general and international civil servants as the key actors and characterizing the member states as an especially important audience for the United Nations. As demonstrated in the sections that follow, the UN Secretariat can (and does) take independent steps either expressly designed to protect the organization's reputationor which have the consequence of affecting the organization's reputation.

To be sure, the United Nations faces some constraints on its choices and its capacity to shape its reputation. But this feature does not make the United Nations unique, or even unusual: organizations and people alike operate under constraints. Consider again private firms contemplating how much they will do to raise labor standards or protect the environment. Their choices are seriously constrained by the market: if they are overly ambitious when it comes to corporate social responsibility, they may drive themselves out of business. ${ }^{77}$ States too are constrained when it comes to shaping their reputations. For example, some states might prefer to cultivate reputations for complying with international law while lacking the capacity to do so; this possibility looms large in the design of compliance mechanisms for many treaties. ${ }^{78}$ The question in each case is how these organizations and entities exercise the discretion that they do have.

A comprehensive account of reputational dynamics would also need to consider more carefully when and why member states seek to preserve and enhance the reputations of the international organizations in which they participate. There are many examples of member states expressing such concerns and, in addition, acting to preserve the organizations' reputations and legitimacy. ${ }^{79}$ But states have competing priorities, and these competing priorities may cause them to take steps that hamper international organizations' ability to protect their reputations. One such competing priority is limiting the organization's overall expenditures-a particular concern for member states that provide significant funds. ${ }^{80}$ Another is the desire to

\footnotetext{
75 Elena Kagan, Presidential Administration, 114 Harv. L. Rev. 2245 (2001).

${ }^{76}$ VoGEL, supra note 12, at 77-79.

${ }^{77} \mathrm{Id}$.

78 See generally Abram Chayes \& Antonia Handler Chayes, The New Sovereignty (1995).

${ }^{79}$ See supra notes 30-31; for a recent example involving Interpol, see Interpol Presidency Vote: Russia in Surprise Loss to North Korea, BBC News (Nov. 21, 2018), at https://www.bbc.com/news/world-europe-46286959

${ }^{80}$ According to press reports, this consideration shaped the United States' response to the cholera outbreak in Haiti under both the Obama and Trump administrations. Colum Lynch, Trump Won't Pay a Penny for U.N. Cholera Relief Fund in Haiti, For. POL'y (June 1, 2017), at https://foreignpolicy.com/2017/06/01/trumpwont-pay-a-penny-for-u-n-cholera-relief-fund-in-haiti.
} 
protect the state's (or government's) own reputation. ${ }^{81}$ Separately, states vary in their willingness to challenge conduct by international organizations that, in their own view, fails to live up to core values. Some will be eager to do so, perhaps welcoming opportunities to speak truth to power. ${ }^{82}$ Other states-especially those that depend upon assistance from the United Nations - may be particularly disinclined to challenge it. ${ }^{83}$ The motivations of individual states-and how they add up to collective action or inaction by the intergovernmental organs of international organizations - remain a topic for future study.

\section{Problematic Responses to Reputational Threats}

Having considered when organizations may be motivated to protect their reputationsand which dimension of their reputation they are seeking to safeguard - this Part considers how organizations respond to reputational damage. Those responses will not always be salutary, and they may even be harmful. In particular, this Part addresses the possibility that organizations will respond to reputational damage (or the threat of such damage) by doing something other than directly and forcefully remedying the source of actual or potential reputational damage. ${ }^{84}$ Put another way, reputations are built on the perceptions and beliefs of an organization's audiences. ${ }^{85}$ Organizations may seek to address reputational damage by focusing on appearances rather than reality. The observation that an organization might do something "merely" to improve its public image captures the idea that efforts undertaken to avoid or to remedy reputational damage may not reflect a sincere or vigorous effort to solve the underlying problem.

\section{A. Symbolic or Cosmetic Responses}

Some forty years ago, two sociologists, John Meyer and Brian Rowan, sought to explain persistent gaps between organizations' formal structures - that is, their organizational charts, express goals, and adopted policies and procedures — and the way that the organizations actually operate on the ground. ${ }^{86}$ Meyer and Rowan argued that organizations face considerable pressure to adopt various formal structures. Such structures may be legally required, a source of social prestige, or standard operating procedures in a professional community. These formal structures contribute to the legitimacy of an organization and help it survive-but not by helping the organization produce its output more efficiently. Thus, for example:

${ }^{81}$ See, e.g., Roland Vaubel, A Public Choice Approach to International Organization, 51 Pub. CHOICE 39, 49 (1986) (suggesting that member states may seek to enhance or preserve their own reputations by shifting blame for unpopular or unsuccessful policies to international organizations in which they participate).

${ }^{82}$ One example is the work of the "Small Five" to enhance the accountability, transparency, and inclusiveness of the Security Council's work a view to strengthening the Council's legitimacy and effectiveness. See generally Joanna Harrington, The Working Methods of the United Nations Security Council: Maintaining the Implementation of Change, 66 INT'L Comp. L. Q. 39 (2017).

83 See, e.g., supra note 65.

${ }^{84}$ Christine Oliver, Strategic Responses to Institutional Processes, 16 AcAD. MGMT. REV. 145 (1991) (setting out a typology of institutional responses to pressure, ranging from acquiescence to defiance, and identifying factors that lead institutions to favor each response).

85 See supra note 18.

${ }^{86}$ John W. Meyer \& Brian Rowan, Institutionalized Organizations: Formal Structure as Myth and Ceremony, 83 Aм. J. Soc. 340 (1977). 
The rise of professionalized economics makes it useful for organizations to incorporate groups of economists and econometric analyses. Though no one may read, understand, or believe them, econometric analyses help legitimate the organization's plans in the eyes of investors, customers (as with Defense Department contractors), and internal participants. Such analyses can also provide rational accountings after failures occur: managers whose plans have failed can demonstrate to investors, stockholders, and superiors that procedures were prudent and that decisions were made by rational means. ${ }^{87}$

When there is a tension or conflict between the formal structures and the logic of efficiency, Meyer and Rowan argue that organizations may respond by "decoupling" the formal structures from the organization's ongoing activities. That is, organizations will adopt the formal structures needed to legitimate the institution, but they may simultaneously insulate their onthe-ground operations from those formal structures. An organization might, for example, adopt equal opportunity hiring procedures on paper while tacitly facilitating noncompliance by declining to collect information about whether and how the policy has been implemented. ${ }^{88}$

Meyer and Rowan do not frame their account in terms of reputation, but other scholars have taken this step. Drawing on Meyer and Rowan's work, the authors of a quantitative study of corporate ethics programs examined the circumstances under which companies adopted easily decoupled policies - i.e., policies that "provide[] the appearance of conformity to external expectations while making it easy to insulate much of the organization from those expectations." 89 The study found that corporations that adopted ethics programs in response to critical media attention were especially likely to choose easily decoupled policies. ${ }^{90}$ The authors expected this result: on the one hand, the targeted corporations would feel a need to placate their critics; ${ }^{91}$ on the other hand, the media's demands would "not necessarily reflect real problems or mesh well with organizational goals." 92 This combination could make easily decoupled policies especially attractive to the corporation's managers.

More recently, sociologists Michael Sauder and Gary Alan Fine observed a similar dynamic in how business schools responded to rankings produced by U.S. News and World Report and other media publications. ${ }^{93}$ Because the rankings play a significant role in shaping the reputation of these institutions - and therefore in attracting students - the stakes are quite high. Business schools respond by "play[ing] to the test" - that is, making various changes, some real and others cosmetic, in order to maximize their scores on various rankings. ${ }^{94}$

${ }^{87} \mathrm{Id}$. at 350 .

${ }^{88} \mathrm{Id}$. at $349,357$.

${ }^{89}$ Gary R. Weaver, Linda Klebe Treviño \& Philip L. Cochran, Integrated and Decoupled Corporate Social Performance: Management Commitments, External Pressures, and Corporate Ethics Practices, 42 ACAD. MGMT. J. 539, 541 (1999).

${ }^{90} \mathrm{Id}$. at 547.

${ }^{91} \mathrm{Id}$. at 542 .

${ }^{92} I$. .

${ }^{93}$ Michael Sauder \& Gary Alan Fine, Arbiters, Entrepreneurs, and the Shaping of Business School Reputations, 23 Soc. F. 699 (2008).

${ }^{94}$ Id. at 712-14. Other key studies include Oliver, supra note 84, and Nils Brunsson, The Organization of HYPOCRISY (1989). 
Other scholars have applied this theoretical approach to international organizations, describing how they engage in "organized hypocrisy" to cope with conflicting demands from member states and others, including NGOs. ${ }^{95}$ Especially important is Catherine Weaver's in-depth study of the World Bank's anti-corruption agenda. ${ }^{96}$ In 1996, James Wolfensohn, the Bank's president, gave a speech touting the Bank's commitment to "deal with the cancer of corruption." 97 Weaver documents how, over the next year, the World Bank did take steps to advance this anti-corruption agenda. These included issuing a new strategy report, hiring more financial managers and procurement specialists, setting up a new internal investigative unit and a twenty-four-hour hotline for reporting corruption, and establishing a "sanctions committee" to punish companies and individuals found guilty of bribery and graft. ${ }^{98}$

Evidence that Wolfensohn's anti-corruption agenda actually changed the Bank's core lending activity is much scarcer, however, as Weaver shows. Middle-income countries that borrowed from the Bank were not keen on the anti-corruption agenda, and the Bank was eager to keep them happy because the interest these countries paid was a key source of the Bank's financial independence. ${ }^{99}$ Individual staff members continued to face incentives to make big loans and make them quickly. ${ }^{100}$ But taking anti-corruption seriously meant provoking confrontations with member states and possibly cancelling loans-or else investing in governance and institutional development projects, which entailed smaller loans, required far more staff time, and involved politically sensitive and contentious negotiations. ${ }^{101}$ Under these circumstances, it is easy to see how a gap between rhetoric and on-the-ground practice- organized hypocrisy—could emerge.

\section{B. Suppressing Damaging Information}

As a logical matter, only information that becomes known outside an organization can harm its reputation. ${ }^{102}$ One strategy for protecting reputation, then, is to hide damaging information. ${ }^{103}$ While all organizations may be tempted by this approach, the temptation

${ }^{95}$ WeAVER, supra note 64; Michael Lipson, Peacekeeping: Organized Hypocrisy, 13 Eur. J. InT'L ReL. 5, 6 (2007); Michael Barnettt \& Liv Coleman, Designing Police: Interpol and the Study of Change in International Organizations, 49 INT'L STUd. Q. 593 (2005).

96 WEAVER, supra note 64.

97 Id. at 108, 121; see also Sebastian Mallaby, The World's Banker 174-206 (2004).

98 WEAVER, supra note 64, at 123.

99 Id. at 121

${ }^{100} \mathrm{Id}$. at 118 .

101 Id. at $118-19$.

${ }^{102}$ A. Rebecca Reuber \& Eileen Fischer, Organizations Behaving Badly: When Are Discreditable Actions Likely to Damage Organizational Reputation, 93 J. Bus. ETHICs 39, 41 (2009); see also Anne Peters, International Organizations and International Law, in The Oxford Handbook of InTERnational Organizations 33, 49 (Jacob Katz Cogan, Ian Hurd \& Ian Johnstone eds., 2016) ("Both member states and outsiders, including affected individuals, will only be able to assess the quality of the operations of an international organization and its impact on themselves if they possess sufficient information on those operations.").

${ }^{103}$ Cf. GUZMAN, supra note 11, at 96 ("Needless to say, a violation of international law generates a reputational sanction only if some other country knows about the violation. It follows that a violation will lead to a smaller reputational loss if fewer countries know about it. By reducing the visibility of their violations, then, states reduce the reputational consequences."); Austin Carson, Facing Off and Saving Face: Covert Intervention and Escalation Management in the Korean War, 70 INT'L ORG. 103 (2016) (arguing that the leaders of governments sometimes act covertly in order to lower the reputational stakes - that is, to avoid pressure from domestic audiences or their 
is worth highlighting here because good reputations are so important to international organizations - and because international organizations have at their disposal a broad array of tools that can help them to conceal derogatory information.

Among the most important tools that allow international organizations to shield harmful information are treaty-based privileges and immunities. International organizations, including the United Nations, often have comprehensive immunities from all forms of legal process. ${ }^{104}$ In addition, the organizations' premises and archives are inviolable. ${ }^{105}$ This inviolability allows organizations to preclude outsiders-including journalists and government officials - from accessing their premises without permission. Inviolability also makes it impossible for outsiders to legally force the disclosure of any information or documents about the organization.

International organizations also have significant discretion and control when it comes to the production of information. Of particular import for sexual violence, international organizations make choices about whether to pursue investigations at all and what kinds of resources to devote to such investigations. By choosing not to initiate investigations, or by limiting their scope, international organizations may be in a position to avoid uncovering information about discreditable actions. ${ }^{106}$ If no such information is uncovered, then there is nothing to hide.

Such investigations (or the absence thereof) matter because, in general, information (both positive and negative) about international organizations' operational work is often hard to come by. International organizations frequently work in places that are relatively difficult to access, thereby making their work difficult to observe. This is certainly true of UN peace operations, which usually involve deployments to volatile and dangerous situations.

There are some important limits, or checks, on international organizations' ability to control information about their activities. Sometimes outsiders are able to develop a detailed account of activities without cooperation from the organization itself. Thus, for example, when a cholera outbreak began in Haiti in 2010, intrepid journalists and epidemiologists quickly uncovered facts that challenged the United Nations' denial of any role in the outbreak. ${ }^{107}$ The United Nations' unwillingness to develop or share key pieces of information slowed down their efforts, but did not stop them. ${ }^{108}$

foreign counterparts to act in a particular way); Scott Dodd, Pennsylvania Grand Jury Says Church Had a "Playbook for Concealing the Truth, "N.Y. Times (Aug. 14, 2018), at https://www.nytimes.com/2018/08/14/us/pennsylvania-child-abuse-catholic-church.html (describing tactics that leaders of the Roman Catholic church in Pennsylvania used regularly for decades to conceal child sexual abuse by priests, as revealed by a grand jury report).

${ }^{104}$ Convention on the Privileges and Immunities of the United Nations, Feb. 13, 1946, 1 UNTS 15; see also Convention on the Privileges and Immunities of the Specialized Agencies, Nov. 21, 1947, 33 UNTS 261.

${ }^{105}$ Convention on the Privileges and Immunities of the United Nations, supra note 104, Art. II, secs. 3-4; Convention on the Privileges and Immunities of the Specialized Agencies, supra note 104, Art. III, secs. 5-6.

${ }^{106}$ Colum Lynch, UN Halted Probe of Officers' Alleged Role in Sex Trafficking, Wash POST. (Dec. 27, 2001) (quoting David Lamb, a former Philadelphia police officer who served as a UN human rights investigator in Bosnia, as saying: "I have to say there were credible witnesses, but I found a real reluctance on the part of the United Nations . . . leadership to investigate these allegations [that UN police were "directly involved in the enslavement of Eastern European women in Bosnian brothels'].”).

${ }^{107}$ For detailed accounts, see Ralph R. Frerichs, Deadly River (2016); Jonathan M. Katz, The Big Truck that Went by: How the World Came to Save Haiti and Left Behind a Disaster 217-44 (2014).

${ }^{108} I d$. 
Sometimes insiders help outsiders overcome both obstacles by leaking information. Officials leak information for many different reasons. ${ }^{109}$ Individuals who are troubled by what they see inside their organizations - and see potential allies in outside NGOs who are agitating for change-may view leaks as a mechanism to promote internal change. ${ }^{110}$

Such leakers, however, may face disciplinary action. To put it mildly, organizations do not always treat leakers - or whistleblowers - as heroes. Over the years, many newspaper stories have described UN officials who were penalized for shedding light on problems. ${ }^{111}$ It is important to take such press accounts with several grains of salt, however. The invocation of the "whistleblower" mantle is often contested, and so too is the characterization of adverse employment consequences as "retaliation." There is more than one side to each story, and the sources on which journalists rely for their reporting may reveal a limited or distorted account. Nevertheless, the basic point stands that punishing staff who reveal damaging information to the public is a troubling way that organizations can seek to avoid reputational harm. In recent years, international organizations have adopted rules and regulations to provide more robust protections to whistleblowers. ${ }^{12}$ But allegations of retaliation against whistleblowers remain quite common, ${ }^{113}$ and international organizations' immunities keep national courts from hearing and perhaps vindicating whistleblowers' claims.

There are also examples of UN officials suppressing damaging information about member states in order to avoid conflicts with those member states. In 2014, a former spokesperson went to the press with allegations that UNAMID, a hybrid African Union and UN peacekeeping mission in Darfur, was underreporting instances of the Sudanese government deliberately targeting Sudanese civilians and UNAMID peacekeepers. ${ }^{114}$ A subsequent investigation initiated by the secretary-general confirmed that the mission withheld information from the media and-more remarkably_even from officials at UN headquarters in New York. ${ }^{115}$

${ }^{109}$ David E. Pozen, The Leaky Leviathan: Why the Government Condemns and Condones Unlawful Disclosures of Information, 127 HARV. L. REV. 512 (2013).

110 See, e.g., WEAVER, supra note 64, at 16 (noting that disillusioned staff members are often quite willing to share stories, draft reports, and internal correspondence, and quoting one Bank staff member who joked that "if a document is marked 'for internal use only,' you can bet the NGOs and newspapers will have it within twenty-four hours").

${ }^{111}$ See, e.g., Colum Lynch, U.N. Sex Crimes Whistle-blower Wrongly Dismissed, For. POL'Y (Sept. 16, 2011), at http://foreignpolicy.com/2011/09/16/u-n-sex-crimes-whistle-blower-wrongfully-dismissed ("Madeleine Rees, a former UN human rights official and the inspiration for one of the heroines in the film The Whistleblower, was wrongfully dismissed from her job with the Geneva-based UN Office of the High Commission for Human Rights in March 2010, according to a ruling by the United Nations' administrative disputes tribunal."); Colum Lynch, U.N. Whistleblower: Expose Corruption at Your Own Peril, For. POL'y (Mar. 19, 2013), at http://foreignpolicy. com/2013/03/19/u-n-whistleblower-expose-corruption-at-your-own-peril (describing decision by UN tribunal awarding \$65,000 in compensation to an American whistleblower, James Wasserstrom, who says that he was forced from his UN job in Kosovo after cooperating in an internal investigation of corruption by UN officials).

112 See, e.g., Robert G. Vaughn, The Successes and Failures of Whistleblower Laws 249-52 (2012).

113 See, e.g., David Kaye (Special Rapporteur), Promotion and Protection of the Right to Freedom of Opinion and Expression, 20, UN Doc. A/70/361 (Sept. 8, 2015).

${ }^{114}$ Colum Lynch, “They Just Stood Watching,"For. PoL’y (Apr. 7, 2014), at http://foreignpolicy.com/2014/04/ 07/they-just-stood-watching-2.

115 UN Secretary-General, Statement Attributable to the Spokesman for the Secretary-General, Review of UNAMID Reporting (Oct. 29, 2014), at https://www.un.org/sg/en/content/sg/statement/2014-10-29/statement-attributable-spokesman-secretary-general-review-unamid (documenting five instances where "the Mission did not provide UN Headquarters with full reports on the circumstances surrounding these incidents, which involved possible wrongdoing by Government or pro-Government forces"); id. (observing that "the Mission 
Fear evidently motivated this self-censorship, at least in part. The UNAMID mission had, in recent years, been subjected to more lethal attacks than any other UN peacekeeping mission, and UNAMID officials reportedly worried that if the United Nations criticized the Sudanese government, the government would engage in reprisals against the peacekeepers. ${ }^{116}$ As Hervé Ladsous, then the under-secretary-general for peacekeeping operations, put it:

In every mission there is a tension between the necessity to preserve the consent and good will of the host government required to allow our peacekeepers to do their jobs and sometimes contradictory imperative to report accurately and candidly on any and all incidents of violence. . . Bad relations with the host government can make it impossible for a mission to operate- to move around the country, to have their equipment cleared by national customs, to deploy new personnel. ${ }^{117}$

In short, as explained in Part I, international organizations have strong incentives to maintain reputations for cooperativeness with member states that supply key resources. This incident involving UNAMID shows that concealing negative information regarding those member states is one way to do it.

\section{The United Nations' Handling of Sexual Violence Allegations in the Central African Republic}

As described in the introduction, the United Nations' handling of allegations of sexual violence, exploitation, and abuse in the Central African Republic has been the source of significant reputational damage — and both government and UN officials have proclaimed their intention to repair that damage. In order to illustrate and deepen the theoretical account of reputational dynamics provided above, this Part takes a closer look at developments in the Central African Republic and the United Nations' key decisions before and shortly after The Guardian sparked widespread interest and attention.

This case study demonstrates some of the constraints under which the UN Secretariat operates when it seeks to preserve its reputation. Most significantly, the United Nations cannot itself prosecute individual perpetrators. Only the government of the individual's nationality can do so. That said, the Secretariat can influence whether or not governments take such actions. The Secretariat has more tools at its disposal with respect to UN peacekeepers than it does with respect to forces that, like the French forces in the Central African Republic (known as Sangaris), are under unified command. Importantly, though, with respect to both sets of actors, UN officials have choices about how often, how forcefully, and how publicly to

took an unduly conservative approach to the media, maintaining silence when it could have developed a press line, even in the absence of all the facts").

${ }^{116}$ Colum Lynch, U.N. Whistleblower Decries “Cover-Up of a Cover-Up” Over Darfur Debacle, For. POL'y (Oct. 29, 2014), at http://foreignpolicy.com/2014/10/29/u-n-whistleblower-decries-cover-up-of-a-cover-up-over-darfur-debacle.

${ }^{117}$ Lynch, supra note 114. For other examples of the United Nations' underreporting violations by a government in order to retain the support of that government for the delivery of humanitarian assistance, see Report of the Secretary-General's Internal Review Panel on United Nations Action in Sri Lanka, Nov. 2012, available at http://www.un.org/News/dh/infocus/Sri_Lanka/The_Internal_Review_Panel_report_on_Sri_Lanka.pdf; Colum Lynch, Congolese Cover-Up, For. POL'Y (Nov. 27, 2018), at https://foreignpolicy.com/2018/11/27/congolese-cover-up-un-congo-murder-zaida-catalan-michael-sharp. 
pressure governments to pursue criminal prosecution. The Secretariat also has discretion over whether and how to facilitate and support criminal investigations by those governments.

The account that emerges is one of the UN Secretariat declining to take key steps that would have avoided or mitigated the reputational damage the organization eventually faced. The failure to avoid yet another sexual abuse scandal and the accompanying media firestorm would seem to support the view that the United Nations is insensitive to reputational costs. In this sense, events in the Central Africa Republic offer a "critical case"118 for evaluating the effectiveness of reputation as a disciplinarian.

\section{A. The United Nations' Involvement in the Central African Republic}

While its roots are deep, the current crisis in the Central African Republic can be traced back to December 2012, when the Séléka, a Muslim rebel group, launched a series of attacks and began marching towards Bangui, the capital. ${ }^{19}$ They eventually seized Bangui and established a brutal and abusive regime. ${ }^{120}$ Seeking to counter the Séléka, a group of former members of the security forces established the mainly Christian anti-Balaka movement and took up arms and killed many people. ${ }^{121}$ The violence took on increasingly sectarian overtones. ${ }^{122}$

In 2013, the Security Council authorized the deployment of two different forces to the Central African Republic. The first force was the "Africa-led International Support Mission in the CAR," known as MISCA, which had been established by the African Union. ${ }^{123}$ The Security Council charged MISCA with contributing to "the protection of civilians and the restoration of security and public order" and to "the stabilization [of] the country and the restoration of State authority over the whole territory of the country." ${ }^{24}$ Separately, the Security Council authorized the French forces in the Central African Republic "to take all necessary measures to support MISCA in the discharge of its mandate." 125 This mission became known as Operation Sangaris. Like traditional UN peacekeepers, MISCA and the French forces operated with the consent of the Central African Republic. But unlike traditional peacekeepers, they did not wear blue helmets or other UN insignia, nor were they under UN command. Instead, they were under the "unified command" of the African Union and France, respectively. ${ }^{126}$

\footnotetext{
${ }^{118}$ Katerina Linos, How to Select and Develop International Law Case Studies: Lessons from Comparative Law and Comparative Politics, 109 AJIL 475, 482 (2015) ("A critical case is one in which a hypothesis would be least likely to hold true, as a matter of theory, and would thus serve as especially powerful evidence in support of the hypothesis.").

${ }^{119}$ MINUSCA, About, at https://minusca.unmissions.org/en/about. For a comprehensive overview of the history of the Central African Republic, see Richard A. BRADSHAW \& JUAN FANDOS-RIUS, Historical DictionaRY OF the Central African Republic 83-132 (2016). For a journalist's account of recent developments, see also John Lee Anderson, The Mission: A Last Defense Against Genocide, New Yorker (Oct. 20, 2014).

${ }^{120}$ Bradshaw \& Fandos-Rius, supra note 119 , at 132.

${ }^{121} I d$. at $126,132-33$.

${ }^{122}$ Id. at 133; MINUSCA, supra note 119.

123 SC Res. 2127, para. 28 (Dec. 5, 2013).

${ }^{124} \mathrm{Id}$.

125 Id., para. 50.

126 Thus, the Security Council requested that the African Union and France report to the Security Council on the implementation of their mandates. Id., paras. 32, 50.
} 
Although MISCA and the French forces had some early successes, the situation on the ground in the Central African Republic deteriorated. ${ }^{127}$ In January 2014, a high-level UN official warned that "the seeds are there, for a genocide," elaborating that the Central African Republic "has all the elements that we have seen elsewhere, in places like Rwanda and Bosnia." 128 The secretary-general recommended replacing MISCA and the French forces with a UN peacekeeping force, on the theory that such a force would be better suited than the French and African Union forces "to address the deep-rooted nature of the complex crisis now unfolding in the Central African Republic."129 The Security Council implemented this recommendation, establishing the MINUSCA peacekeeping force to replace MISCA in September 2014. ${ }^{130}$

In May 2014-while the French and MISCA forces were still on the ground in the Central African Republic, and before the MINUSCA forces were constituted-UN officials in Bangui heard from the head of a local NGO that some foreign military troops had subjected children to sexual acts in exchange for food or money in the vicinity of the nearby M'Poko Internally Displaced Persons Camp. ${ }^{131}$ Between May 19 and June 24, Gallianne Palayret, a human rights officer temporarily deployed to the UN office in Bangui, together with the UN International Children's Emergency Fund (UNICEF) protection officers, interviewed six children, all boys between eight and eleven years old. ${ }^{132}$ Three boys told Palayret that they had performed oral sex on French Sangaris soldiers in exchange for food and money. ${ }^{133}$ A fourth boy, nine years old, told her that he was about to do the same but stopped after being seen by another child, who alerted others. ${ }^{134}$ The fifth and sixth boys interviewed said they had witnessed other boys perform oral sex in exchange for food or money. ${ }^{135}$ The sixth boy, eleven years old, also reported that two of those boys had also been raped on other occasions. ${ }^{136}$

A leaked copy of Palayret's interview notes-coupled with an account of the organization's lackadaisical response to the allegations-formed the core of Sandra Laville's article in The Guardian, published at the end of April 2015. ${ }^{137}$ According to Laville's news story, the only person against whom the organization moved forcefully was Anders Kompass, the whistleblower who brought the allegations to the attention of the French government. ${ }^{138}$

\footnotetext{
${ }^{127}$ UN Secretary-General, Report of the Secretary-General on the Central African Republic, para. 35, UN Doc. S/2014/142 (Mar. 3, 2014).

${ }^{128}$ Emmanuel Braun \& Tom Miles, "Seeds of Genocide" in Central African Republic, U.N. Warns, ReuTERs (Jan. 17, 2014), at http://www.reuters.com/article/us-centralafrican-idUSBREA0G02520140117.

${ }^{129}$ Report of the Secretary-General on the Central African Republic, supra note 127, para. 55.

130 SC Res. 2146, paras. 20-21 (Apr. 10, 2014). The full name of MINUSCA is the United Nations Multidimensional Integrated Stabilization Mission in the Central African Republic.

${ }^{131}$ CAR Panel Report, supra note 33, at 17.

${ }^{132}$ Id.; Nick Cumming-Bruce, U.N. Official Says French Learned Early of Abuse, N.Y. Times (Oct. 15, 2015), at http://www.nytimes.com/2015/10/15/world/africa/un-official-says-french-learned-early-of-abuse.html.

${ }^{133}$ CAR Panel Report, supra note 33, at 17.

$134 \mathrm{Id}$

$135 \mathrm{Id}$.

${ }^{136} \mathrm{Id}$.

137 See supra note 1.

${ }^{138} I d$.
} 
Two months later, Secretary-General Ban Ki-moon appointed an independent panel to review the United Nations' response to the allegations against the Sangaris. ${ }^{139}$ The panel report (hereinafter CAR Panel Report), released in December 2015, excoriated the United Nations' handling of the allegations:

[I]nformation about the Allegations was passed from desk to desk, inbox to inbox, across multiple United Nations offices, with no one willing to take responsibility to address the serious human rights violations. . . . The welfare of the victims and the accountability of the perpetrators appeared to be an afterthought, if considered at all. Overall, the response of the UN was fragmented and bureaucratic, and failed to satisfy the core mandate of the United Nation to address human rights violations. ${ }^{140}$

Meanwhile, the allegations did not lead to any prosecutions in French courts. In December 2015, four French soldiers were formally detained and interrogated. ${ }^{141}$ Just over a year later, a panel of French judges made a preliminary decision not to seek charges against the Sangaris soldiers accused of sexually abusing children. ${ }^{142}$ In January 2018, magistrates in France closed the investigations and dismissed any prospect of a trial, citing insufficient evidence. ${ }^{143}$

Separate from these allegations against the French Sangaris, once MINUSCA was established, the United Nations faced a separate crisis involving sexual violence by UN peacekeepers in the Central African Republic. That there was a problem-and that its severity was unusual - was revealed little by little. After The Guardian story broke, the United Nations became more forthcoming about additional allegations. During the summer of 2015, the press covered news of allegations against peacekeepers in the Central African Republic, some but not all of which involved sexual violence. ${ }^{144}$

On August 12, Babacar Gaye, the special representative for the secretary-general in the Central African Republic and the head of the MINUSCA office in Bangui, resigned at the

${ }^{139}$ UN Press Release, Secretary-General Appoints Independent Review Panel on UN Response to Allegations of Sexual Abuse by Foreign Military Forces in Central African Republic, UN Press Release SG/SM/16864-SG/A/1578 (June 22, 2015), at https://www.un.org/press/en/2015/sgsm16864.doc.htm.

${ }^{140}$ CAR Panel Report, supra note 33, at 2.

${ }_{141}$ Angelique Chrisafis, French Soldiers Interrogated in Child Sex Abuse Inquiry, GuARDIAN (Dec. 8, 2015).

142 Benoît Morenne, No Charges in Sexual Abuse Case Involving French Peacekeepers, N.Y. Times (Jan. 6, 2017), at https://www.nytimes.com/2017/01/06/world/africa/french-peacekeepers-un-sexual-abuse-case-central-african-republic.html.

${ }^{143}$ Child Rape Allegations Against French Troops in C.A.R. Dismissed, AfricaNews (Jan. 15, 2018), at http:// www.africanews.com/2018/01/15/child-rape-allegations-against-french-trooops-in-car-dismissed.

${ }^{144}$ UN Mission in Central African Republic Opens Investigation into Sexual Abuse Claims, UN News CENTRE (June 4, 2015), at https:/www.un.org/apps/news/story.asp?NewsID=51057 (acknowledging the UN office in Bangui received an allegation that a peacekeeper had engaged in "sexual abuse of an underage person"); AFP, New Child Sex Abuse Claims Target UN Peacekeepers in Central African Republic, TeLEgraPH UK (June 24, 2015), at http://www.telegraph.co.uk/news/worldnews/africaandindianocean/centralafricanrepublic/11695311/ New-child-sex-abuse-claims-target-UN-peacekeepers-in-Central-African-Republic.html (describing new allegations that UN peacekeepers had sexually abused street children in Bangui); Somini Sengupta, Police Officer With U.N. Force in Central African Republic Is Accused of Rape, N.Y. TIMES (Aug. 11, 2015), at https://www. nytimes.com/2015/08/12/world/africa/police-officer-with-un-force-in-central-african-republic-is-accused-ofrape.html (describing Amnesty International report that accused UN police from Cameroon and Rwanda of indiscriminately firing at civilians in Bangui and of raping a twelve-year-old girl). 
request of the secretary-general. ${ }^{145}$ The UN spokesperson explained that the request was "based on the repeated number of cases of sexual abuse and misconduct that have taken place in the Central African Republic." 146 The spokesperson provided no further detail, but described the resignation as "unprecedented," 147 relating that he had not seen anything like it during his fifteen years at the United Nations. ${ }^{148}$

Within days of Gaye's resignation, still more rape allegations against MINUSCA peacekeepers were reported. ${ }^{149}$ The United Nations did not directly identify the nationalities of the accused, but a UN spokesperson indicated that the rapes took place in a market town where peacekeepers from the Democratic Republic of Congo (DRC) had been serving. ${ }^{150}$

It later became clear that including troops and police from the DRC in MINUSCA was quite controversial within the UN Secretariat from the beginning because a UN report authored by the secretary-general had identified the armed forces of the DRC (FARDC) among parties that "recruit and use children" and that "commit rape and other forms of sexual violence against children." 151 Although some UN officials objected, the Secretariat ultimately made the decision to include in MINUSCA an infantry battalion and a formed police unit from the DRC. ${ }^{152}$

Subsequent developments revealed that concerns about the DRC troops and police were warranted. On January 8, 2016, the UN spokesperson announced that a contingent from the DRC currently deployed in MINUSCA would be "repatriated without replacement."153 Although the United Nations did not acknowledge it immediately, it later became clear that the DRC's deficient response to numerous sexual violence allegations prompted the repatriation. ${ }^{154}$

\footnotetext{
${ }^{145}$ Full Transcript of Secretary-General's Remarks to Press on the Central African Republic (Aug. 12, 2015), at https://www.un.org/sg/en/content/sg/press-encounter/2015-08-12/full-transcript-secretary-generals-remarkspress-central.

${ }^{146}$ UN Press Release, Daily Press Briefing by the Office of the Spokesperson for the Secretary-General (Aug. 12, 2015), at https://www.un.org/press/en/2015/db150812.doc.htm.

147 Id.

$148 \mathrm{Id}$.

${ }^{149}$ Somini Sengupta, 3 Peacekeepers Accused of Rape in Central African Republic, N.Y. Times (Aug. 19, 2015), at https:/www.nytimes.com/2015/08/20/world/africa/3-peacekeepers-accused-of-rape-in-central-african-republic. html.

${ }^{150} \mathrm{Id}$.

${ }^{151}$ UN Secretary-General, Children and Armed Conflict, Annex I, UN Doc. A/68/878-S/2014/339 (May 15, 2014). Somini Sengupta, U.N. Officials Warned That Congolese Soldiers Were Linked to Rape, N.Y. TimES (Mar. 17, 2016), at https://www.nytimes.com/2016/03/18/world/africa/un-officials-warned-that-congolese-soldiers-werelinked-to-rape.html.

152 UN Secretary-General, Report of the Secretary General on the Situation in the Central African Republic, UN Doc. S/2014/857 (Nov. 28, 2014).

${ }^{153}$ UN Press Release, Daily Press Briefing by the Office of the Spokesperson for the Secretary-General (Jan. 8, 2016), at http://www.un.org/press/en/2016/db160108.doc.htm (citing lack of progress in meeting UN requirements for "equipment, vetting and preparedness").

${ }^{154}$ UN Secretary-General, Special Measures for Protection from Sexual Exploitation and Sexual Abuse, para. 25, UN Doc. A/70/729 (Feb. 16, 2016) (providing data on allegations of sexual exploitation and abuse from January 1 to December 31, 2015) [hereinafter 2016 SEA Report]; Somini Sengupta, U.N. Officials Warned That Congolese Soldiers Were Linked to Rape, N.Y. Times (Mar. 17, 2016), at https://www.nytimes.com/2016/ 03/18/world/africa/un-officials-warned-that-congolese-soldiers-were-linked-to-rape.html; Anthony Banbury, Opinion, I Love the U.N., but It Is Failing, N.Y. Times (Mar. 18, 2016), at https://www.nytimes.com/2016/ 03/20/opinion/sunday/i-love-the-un-but-it-is-failing.html.
} 


\section{B. Reputational Multiplicities and the UN's Response to Developments in the Central African Republic}

The reputational damage inflicted on the United Nations in the wake of revelations concerning the Sangaris and UN peacekeepers in the Central African Republic was hardly unpredictable. So why run the risk of such grave damage to the organization by sitting on the allegations against the Sangaris and by accepting peacekeepers from the DRC in light of their military's abysmal track record on sexual violence-a fact publicized by the United Nations itself? ${ }^{155}$ Reputational multiplicities can help to explain actions or policies on the part of certain UN officials that initially appear somewhat puzzling.

\section{Initial handling of the allegations against the Sangaris}

Once the United Nations office in Bangui learned about the allegations against the French soldiers, it did not act quickly to escalate the matter within the United Nations. The CAR Panel Report faulted Renner Onana, who was at the time the head of the Human Rights and Justice Section of the MINUSCA office in Bangui. ${ }^{156}$ The Report criticized Onana's failure to take urgent action to halt further abuse, to identify the perpetrators, and to ensure that they were held accountable. ${ }^{157}$ Rather than pulling fire alarms and insisting that the allegations get high-level attention, the Report said, Onana downplayed the allegations. He never wrote a report focused specifically on the allegations; instead, Onana included descriptions of them in two other reports where they did not obviously belong. ${ }^{158}$

The CAR Panel Report suggests two motivations for Onana's handling of the allegations. When he first shared news of the allegations with Gaye in May 2014, Onana expressed his concern that "disclosure of the Allegations would seriously harm the mission and destroy the trust of the local population in the international forces." 159 Onana was thinking of the organization's reputation in the eyes of the community in which the United Nations was operating. Of course, the "local population" that Onana had in mind implicitly excluded the victims of the Sangaris soldiers and those who are close to them. Their estimation of the United Nations was surely not improved by downplaying or ignoring the allegations. One might also criticize Onana for misjudging how to best preserve the organization's reputation in the broader local community. Efforts to protect reputation require predictions about how others will react, and those predictions will not always be correct. In this case, forthrightly acknowledging the allegations - and focusing on an appropriate response, including care for the victims and investigation of the

155 See supra note 151.

${ }^{156}$ Colum Lynch, The U.N. Official Who Blew the Lid off Central African Republic Sex Scandal Vindicated, For. PoL'Y (Dec. 17, 2015), at http://foreignpolicy.com/2015/12/17/the-u-n-official-who-blew-the-lid-on-centralafrican-republic-sex-scandal-vindicated. The CAR Panel Report concluded that Onana had abused his authority. CAR Panel Report, supra note 33, at 7.

157 CAR Panel Report, supra note 33, at 7.

${ }^{158} \mathrm{Id}$. at 32-35, 52-54 (describing how Onana included the allegations in a report about re-hatting MISCA soldiers for MINUSCA, and in a report on a comprehensive report on human rights violations committed by all foreign forces in the Central African Republic, and noting that the latter was never even finalized).

159 Id. at 61 . 
perpetrators - may have been the best way to show respect for the local community and to regain some good will. ${ }^{160}$

Second, Onana explained in his statement to the panel that he considered the allegations extremely politically sensitive because of his personal experience, just two months prior, dealing with allegations of human rights violations involving MISCA forces from Chad. ${ }^{161}$ At the end of March 2014, Chadian soldiers that were part of MISCA had fired on a crowd in the suburb of Begoua, allegedly killing twenty-four people and injuring about one hundred. ${ }^{162}$ Some reports indicated that the soldiers had fired indiscriminately and without provocation. ${ }^{163}$ The Chadian government was furious when the United Nations publicly addressed the allegations, and painted itself as the victim of a "gratuitous and malicious campaign."164 Within a week, the Chadian government announced that it was withdrawing eight hundred troops from the Central African Republic. ${ }^{165}$ That withdrawal had serious practical consequences: Chadian troops had been instrumental in helping to evacuate Muslims threatened by violence in the country. ${ }^{166}$ Onana worried that the French government might react in a similar way to news of the allegations against the Sangaris. ${ }^{167}$ Finding replacements would have been especially difficult because, for troops not under UN command, the organization usually takes a "costs lie where they fall" approach—that is, the expenses for such missions are typically borne by the participating member states. ${ }^{168}$

In short, Onana viewed the allegations as potentially threatening the United Nations' relationship with the French government. Put another way, Onana saw a risk to the organization's reputation for cooperativeness with a state that was a supplier of key resources in the Central African Republic_-and also a permanent member of the Security Council. And a damaged relationship with France could threaten the effectiveness of the peace operation on the ground. On this point too, Onana may have misjudged the reaction of the French government. Gallianne Palayret, who sought a meeting with the French forces after concluding the first interview, described their reaction in positive terms, saying they took the allegations seriously. ${ }^{169}$ Later, when Anders Kompass shared the allegations with high-level French

${ }^{160}$ Cf. Daugirdas 2019, supra note 14 (quoting an NGO advocate criticizing the United Nations' handling of the cholera outbreak in Haiti saying: "The way to contribute to public anger is to lie.").

${ }^{161}$ CAR Panel Report, supra note 33, at 51-52.

${ }^{162}$ UN Press Release, Press Briefing Note on Central African Republic, Spokesperson for the UN High Commissioner for Human Rights: Cécile Pouilly (Apr. 1, 2014), at http://www.ohchr.org/EN/NewsEvents/ Pages/DisplayNews.aspx?NewsID=14466.

${ }^{163}$ Id.

${ }^{164}$ Steve Niko \& Krista Larson, Chad Pulls Troops from Central Africa; Decries Scrutiny After Peacekeepers Fired into Crowd, Boston Globe (Apr. 4, 2014).

$165 \mathrm{Id}$

$166 \mathrm{Id}$.

${ }^{167}$ CAR Panel Report, supra note 33, at 51-52.

168 See, e.g., SC Res. 1264, para. 9 (Sept. 15, 1999) ("stresses that the expenses for the force will be borne by the participating Member States concerned”). See generally Laurence Boisson de Chazournes, Interactions BetweEn Universal and Regional InTERnATIONAL Organizations (2017).

${ }^{169}$ Envoyé spécial : Viols en Centrafrique: l'armée savait-elle plus tôt qu'elle ne le dit?. France 2 (Oct. 2, 2015), at https://www.francetvinfo.fr/replay-magazine/france-2/envoye-special/video-envoye-special-centrafrique-scandale-dans-1-armee-francaise_1108137.html [hereinafter France 2 Envoyé spécial]; see also Nick Cumming-Bruce, U.N. Official Says French Learned Early of Abuse, N.Y. TimEs (Oct. 14, 2015), at https://www.nytimes.com/2015/ 10/15/world/africa/un-official-says-french-learned-early-of-abuse.html. For a discussion of subsequent events, see infra Part III.D.2. 
diplomats in Geneva and New York, the French government immediately sent a team of investigators to the Central African Republic. ${ }^{170}$ After the story in The Guardian, thenFrench President Francois Hollande said: "If some soldiers have behaved badly, I will show no mercy." 171 A joint statement from the foreign and defense ministries underscored this view: "The defence ministry has taken and will take all necessary measures to ensure the truth comes out. ... If proved true, it will ensure that the toughest sanctions are imposed on those responsible for what would be a terrible breach of the values of a soldier." 172 In a subsequent statement, Hollande acknowledged that France's own reputation was on the line:

We cannot - and I cannot-accept the least stain on the reputation of our armed forces - that is to say, on the reputation of France. It would be the honor of France that would be engaged, and that is why the greatest commitment to the truth and against impunity must be expressed today by the head of state personally. ${ }^{173}$

These public reactions suggest that the allegations did not threaten the relationship between the United Nations and France, as Onana feared. Hollande's comments about France's reputation are particularly telling. He clearly perceived a risk to the country's reputation-but the source of the reputational damage would be the impunity of the perpetrators.

Of course, at the time that Onana was acting, he did not know how the French would react. In his response to the external panel report, Onana suggested that his desire to avoid a confrontation with the French government was not idiosyncratic; in fact, he maintained such a view was widespread within the United Nations, and an important reason for the organization's desultory response to the allegations against the Sangaris:

Rather than scapegoat [me] for failure to act, I strongly ascribe this to a system failure, given that nobody from the [head of mission] to NY and Geneva wanted to take the full responsibility for necessary action for fear that the allegations involved a powerful P5 member of the [Security Council]. ${ }^{174}$

This apparent organizational imperative to maintain a reputation for cooperativeness with member states aligns with the micro-level incentives that individual UN employees face. Picking fights with member states is not generally a good way for UN officials to advance their careers within the organization. ${ }^{175}$ Individual officials may be particularly reluctant

${ }^{170}$ CAR Panel Report, supra note 33, at 46.

${ }^{171}$ Angelique Chrisafis \& Sandra Laville, Hollande: No Mercy Over Claims French Soldiers Abused Children in CAR, GUARDIAN (Apr. 30, 2015), at https://www.theguardian.com/world/2015/apr/30/hollande-no-mercy-overallegations-of-child-abuse-in-car-by-french-soldiers.

${ }^{172}$ Sandra Laville, France Promises to Act After Leaked UN Report Says Its Soldiers Abused Children, GUARDIAN (Apr. 29, 2015), at https://www.theguardian.com/world/2015/apr/29/france-promises-act-leaked-un-report-soldiers-child-abuse-claims.

173 Centrafrique: <<l’honneur de la France serait engagé >> déclare François Hollande, LIBÉRATION (Apr. 2, 2016), at https://www.liberation.fr/planete/2016/04/02/centrafrique-l-honneur-de-la-france-serait-engagedeclare-francois-hollande_1443536 (translated by the author).

${ }^{174}$ Comments of the Head of the Human Rights \& Justice Section, MINUSCA, CAR Panel Report, supra note 33, at Appendix C.1, at para. 21.

${ }^{175}$ Cf. Mac Darrow \& Louise Arbour, The Pillar of Glass: Human Rights in the Development Operations of the United Nations, 103 AJIL 446, 453 (2009) ("[F]or a resident coordinator to be ... declared persona non grata, that is, asked by the government to leave the country . . . is no badge of honor. To the contrary, experience shows that losing favor with the host government may retard senior officers' career prospects and, in some cases, undermine or 
to provoke such confrontations in cases where they deem the allegations not very serious. ${ }^{176}$

There was, however, one high-level official who was willing to publicly criticize the French government's handling of the allegations against the Sangaris - the UN High Commissioner for Human Rights, Zeid Ra'ad Zeid Al-Hussein. Shortly after The Guardian story was published, Al-Hussein gave a press conference during which he repeatedly asked why France had not investigated its own soldiers in the months before the United Nations' own investigation:

How is it that nobody knew about these abuses between December and May [when the alleged conduct occurred]? .. . If you have a fever for five months, you don't need a doctor to come in at the fifth month to tell you you're not well. ${ }^{177}$

Al-Hussein may have been more willing than other UN officials to confront the French government because of his particular position. The UN High Commissioner is selected for his or her expertise and commitment to human rights. ${ }^{178} \mathrm{Al}$-Hussein saw his willingness to confront member states as central to fulfilling his obligations. In December 2017, he announced that he would not seek a second term, explaining that doing so "in the current geopolitical context ... might involve bending a knee in supplication; muting a statement of advocacy; lessening the independence and integrity of my voice . . .."179 In reputational terms, Al-Hussein appeared to focus on his personal reputation and that of his office rather than the United Nations in its entirety.

A focus on the mission — and by extension the reputation — of a particular unit rather than the organization as a whole can also help to explain the reluctance of individuals within the Office of the High Commissioner for Human Rights (OHCHR) to aid French investigators once they arrived in Bangui. Whether the perpetrators of sexual violence face criminal prosecution and punishment is a central question for evaluating the United Nations' overall handling of allegations of sexual violence. But it is less central to the mission and culture of OHCHR, whose officials focus more on protecting victims and harbor significant doubts about the sincerity and quality of member states' criminal investigations. The OHCHR officials who spoke with the members of the Panel repeatedly emphasized the principle of "do no harm," and the victims' and witnesses' rights to privacy, confidentiality, and informed

delay the implementation of the UN projects in the country concerned."); see also supra notes 69-71 (addressing how individual reputations relate to organizational reputation).

176 The literature on rape perception identifies some of the factors that may cause individuals to blame victims or to exonerate perpetrators - and therefore not take allegations seriously. See, e.g., Amy Grubb \& Emily Turner, Attribution of Blame in Rape Cases: A Review of the Impact of Rape Myth Acceptance, Gender Role Conformity and Substance Use on Victim Blaming, 17 Aggression \& Violent BehaV. 443 (2012); Irina Anderson, What Is a Typical Rape? Effects of Victim Participant Gender in Female and Male Rape Perception, 46 BRIT. J. Soc. PsYCH. 225 (2007).

${ }^{177}$ Somini Sengupta, U.N. Official Accuses France of Delays in Child Sexual Abuse Case, N.Y. Times (May 9, 2015), at https://www.nytimes.com/2015/05/09/world/africa/un-official-accuses-france-of-delays-in-child-sexual-abuse-case.html.

${ }^{178}$ GA Res. 48/141, para. 2(a) (Dec. 20, 1993).

${ }^{179}$ Somini Sengupta \& Nick Cumming-Bruce, Zeid Ra'ad al-Hussein, Top Human Rights Official, Won't Seek a Second Term, N.Y. Times (Dec. 20, 2017), at https://www.nytimes.com/2017/12/20/world/un-human-rights-alhussein.html. 
consent. ${ }^{180}$ Al-Hussein even suggested that there were no circumstances in which it would have been appropriate for Kompass to share with French diplomats the names of the alleged victims because it was "virtually impossible" for those children to provide their prior informed consent to sharing such information. ${ }^{181}$ Along similar lines, Renner Onana, the head of the MINUSCA Human Rights and Justice Office, suggested that the French investigators who arrived in August 2014, were decidedly unwelcome. He described the investigators as "endanger[ing]" the victims and "severely compromis[ing]" the efforts that his office and UNICEF had made to protect them. ${ }^{182}$ Onana did not elaborate, so it is unclear whether there are particular features of the investigation or simply the very fact of it that he found troubling. The point stands, though, that there is some tension between OHCHR's focus on protecting victims and the broader organization's interest in ensuring that perpetrators of sexual violence do not evade accountability through national criminal justice proceedings.

\section{Accepting troops from the DRC}

The importance to the United Nations overall of maintaining a cooperative relationship with key member states also featured in the decision by the UN Secretariat to accept peacekeepers from the DRC notwithstanding the known risks associated with those troops. To start, when the Security Council created MINUSCA, it specifically asked the Secretariat "to include in MINUSCA as many MISCA military and police personnel as possible and in line with United Nations standards." 183 Troops from the DRC were participating in MISCA. Categorically excluding DRC troops from MINUSCA would have put the organization (and individual officials) in a position of snubbing a member state, and perhaps subjected it to complaints that the Secretariat was disregarding the Security Council's specific instructions.

For the Secretariat, another challenge to implementing the Security Council's resolution was simply finding enough soldiers to do the job-and finding them quickly. As reported by the press:

Hervé Ladsous, the United Nations' under secretary general for peacekeeping, said he was aware of the risks of deploying the battalion from the Democratic Republic of Congo, but he was also under orders from the Security Council to mobilize a large, robust force to prevent mass atrocities in the Central African Republic. . . .

"In peacekeeping, the hard reality is that there is a constant tension between the need to deploy peacekeepers quickly to stabilize a fragile situation and the requirement to ensure that only the highest quality troops are sent to implement our mandated tasks," Mr. Ladsous said in an email. "The U.N. has no forces of its own, and is dependent on the member states to provide professional forces at a high state of readiness." 184

\footnotetext{
180 See, e.g., Comments of the High Commissioner for Human Rights, CAR Panel Report, supra note 33, at Appendix C.5, at 2 ; id. at 60 .

${ }^{181}$ Id. at Appendix C.5, at 2.

${ }^{182}$ Id. at Appendix C.1, para. 14 \& final observation iv.

183 SC Res. 2149, para. 22 (Apr. 10, 2014).

${ }^{184}$ Sengupta, supra note 151.
} 
Similar concerns delayed the repatriation of the DRC contingent. After the repatriation decision in January 2017, "Mr. Ladsous insisted that they remain for more than a month, arguing that the risk of violence around the Central African Republic's February election was too high to pull out an entire battalion." 185

In general, finding the peacekeeping troops to implement the mandates that the Security Council writes is a difficult job for the Secretariat. In recent decades, as peacekeeping missions have grown more numerous and less safe, the job has become even harder. The countries that participate in peacekeeping missions receive financial compensation for personnel and equipment at rates set by the General Assembly, but this compensation is not enough to close the gap between supply and demand for peacekeepers. Unlike the salary scales for UN officials, which are designed to make those jobs attractive and competitive across the entire world, the reimbursement rates for peacekeepers are set at a fairly low level: for example, troop-contributing countries are reimbursed at a rate of $\$ 1,410$ per soldier per month. ${ }^{186}$ Some poorer states may realize financial gains from supplying peacekeepers. For wealthier member states, however, these rates mean that supplying peacekeepers necessarily involves a sizeable in-kind voluntary contribution.

The pressure to meet the demand for peacekeepers, coupled with the desire to avoid confrontation with member states, has sometimes caused the organization to accept troop and police contingents that fail to meet the United Nations' own standards. ${ }^{187}$ Parfait Onanga-Anyanga, who replaced Babacar Gaye as the head of the UN mission in the Central African Republic, gave an interview shortly after the repatriation of the DRC contingent. Describing the MINUSCA troops, Onanga-Anyanga was unusually blunt. He said: "We inherited troops that we cannot call troops. I realized that what was sent here was trash."188

UN officials are usually much more restrained in their public comments because they recognize that their actions and comments affect not only on the United Nations' reputation, but also the reputations of UN member states. ${ }^{189}$ It is embarrassing for troop-contributing countries to be associated with poor discipline or misconduct generally-and all the more so to be associated with sexual exploitation and abuse. ${ }^{190}$ The desire to avoid such reputational harm can inhibit states from contributing personnel in the first place. ${ }^{191}$ It can also cause

$185 \mathrm{Id}$.

${ }^{186}$ UN Peacekeeping, Deployment and Reimbursement, at https://peacekeeping.un.org/en/deployment-andreimbursement.

187 See, e.g., Chuck Call \& Michael Barnett, Looking for a Few Good Cops: Peacekeeping, Peacebuilding, and CIVPOL, 6 InT'L PEACEKEEPING 43, 51 (1999) ("Even the common, basic requirements of being able to drive a vehicle and to speak the language of the mission are not consistently met.").

${ }^{188}$ Kevin Sieff, "Sometimes When I'm Alone with My Baby, I Think About Killing Him. He Reminds Me of the Man Who Raped Me," WaSH. Post (Feb. 28, 2016).

${ }^{189}$ See, e.g., William Branigin, Tarnishing U.N.'s Image in Cambodia, WASH. Post, Oct. 29, 1993, at A33 (after describing numerous misdeeds of Bulgarian peacekeepers deployed to Cambodia, closing with quotation from a UN spokesperson who said that while the Bulgarian peacekeepers had "behave[d] in a way that would make all of us blush," repatriating the unit was out of the question because "[i]t would be a terrible insult").

${ }^{190}$ See, e.g., comments by Egypt during the Security Council debate leading to the adoption of Security Council Resolution 2272: "Egypt believes that cases of sexual exploitation and abuse should not be used as a tool to attack troop-contributing countries or their reputation, or to undermine the significant sacrifice they are undertaking to re-establish peace and security for civilians." UN SCOR, 71st Sess., $7642 \mathrm{~d}$ mtg., at 10, UN Doc. S/PV.7642 (Mar. 10, 2016).

${ }^{191}$ See also Alex J. Bellamy \& Paul D. Williams, Explaining the National Politics of Peacekeeping Contributions, in Providing Peacekeepers: The Politics, Challenges, and Future of United Nations Peacekeeping 
states to withdraw troops that they have already contributed. ${ }^{192}$ Finally, it can affect which UN policies states choose to support. At the 2016 Security Council meeting that led to a resolution on sexual exploitation and abuse, the United States proposed text that endorsed repatriation and replacement of all military and formed police units where the contributing country failed to investigate allegations of sexual exploitation and abuse and hold perpetrators accountable. ${ }^{193}$ The Egyptian representative objected on the grounds that this provision would "allow taking arbitrary and unobjective decisions" that would "tarnish the reputation of troop-contributing countries." 194 In the end, an amendment he proposed failed to pass, and the text proposed by the United States was adopted. ${ }^{195}$ The Egyptian representative emphasized, though, that in the General Assembly, where troop-contributing countries have more influence, that resolution "never would have been adopted."196

This basic dynamic - an international organization overlooking instances where member states have not complied with the organization's own rules or demands in order to keep resources flowing — can be found outside the United Nations as well. Take the World Bank, for example. Its loans to member states typically come with strings: there are various conditions that member states agree to satisfy before the Bank will extend the loans. At least historically, the Bank would often overlook violations of those and terms and conditions. ${ }^{197} \mathrm{~A}$ key reason was the desire to retain a cooperative relationship with interest-paying borrowing states to ensure that they keep borrowing - and thereby supply funds for the Bank's ongoing operations. ${ }^{198}$

In reputational terms, both of these examples highlight just how much care international organizations will take to retain reputations for cooperativeness with and responsiveness to a key audience: those states that provide essential resources to the organization.

\section{Problematic Responses: Zero Tolerance as an Empty Gesture?}

The dynamics between the United Nations and countries that supply troops for UN peace operations suggest that, when it comes to efforts to address sexual violence by UN peacekeepers and others implementing UN mandates, the United Nations faces the kinds of

Contributions 417, 420 (Alex J. Bellamy \& Paul D. Williams eds., 2013) (identifying "the potential for peacekeeping to damage the national reputation" as a political factor inhibiting participation in peacekeeping); Jonah Victor, African Peacekeeping in Africa: Warlord Politics, Defense Economics, and State Legitimacy, 4 J. PEACE RES. 217 (2010) (evaluating participation of African states in peacekeeping operations in Africa, and finding that states that are poorer, with lower state legitimacy and lower political repression, participate more often in regional peacekeeping).

192 See, e.g., Chris McGreal, Stop Protecting Peacekeepers Who Rape, Ban Ki-moon Tells UN Member States, GuARDIAN (Sept. 17, 2015), at https://www.theguardian.com/world/2015/sep/17/stop-protecting-peacekeepers-who-rape-ban-ki-moon-tells-un-member-states ("Some countries, notably Nigeria, Rwanda and India, have threatened to pull their troops out of peacekeeping if they are exposed publicly on abuses, sexual and otherwise."). For a parallel example involving a threat to withhold funding if the secretary-general included Saudi Arabia in a report documenting abuses of children during armed conflict, see Colum Lynch, U.N. Chief Says He Went Soft on Saudi Arabia and Allies to Avoid Aid Cut, For. POL'y (June 9, 2016), at https://foreignpolicy.com/2016/06/09/un-chief-says-he-went-soft-on-saudi-arabia-and-allies-to-avoid-aid-cut.

193 SC Res. 2272, para. 2 (Mar. 11, 2016).

${ }^{194}$ UN SC, 7643d Mtg., Mar. 11, 2016, UN Doc. S/PV.7643, at 2.

${ }^{195} \mathrm{Id}$.

${ }^{196} \mathrm{Id}$.

197 Ngaire Woods, The Globalizers 4 (2006); Weaver, supra note 64, at 58-59.

198 See supra notes 63-64 and accompanying text. 
contradictory institutional pressures that may make symbolic or cosmetic approaches especially tempting. This section reviews the development and evolution the United Nations' zero tolerance policy" regarding sexual exploitation and abuse in 2005, nearly a decade before the allegations against the Sangaris surfaced. ${ }^{199}$ Kofi Annan promulgated this policy in response to revelations of sexual exploitation and prostitution in UN refugee camps in Guinea, Liberia, and Sierra Leone following the leak of a report prepared for the Office of the UN High Commissioner for Refugees (UNHCR) in 2002. ${ }^{200}$ Michael Lipson has argued that the United Nations' response to these revelations was a manifestation of organized hypocrisy: in his view, the adoption of the policy, coupled with a handful of statements expressing outrage, constituted a deliberate substitute for real changes. ${ }^{201}$ The CAR Panel Report is similarly dismissive of the zero-tolerance policy, declaring that it "has had little effect" 202 If the zero-tolerance policy was an empty gesture, perhaps the United Nations' mishandling of sexual violence in the Central African Republic is the expected result.

This section questions that characterization. Lipson is surely right that the conflicting demands and multiple audiences the United Nations faces may make a purely symbolic response tempting. A closer look at the aftermath of that policy's adoption suggests, however, that classifying an organization's response as either symbolic or sincere is not so easy. Steps that might be written off as symbolic may in fact be positive incremental steps that are necessary but, by themselves, insufficient to address the problem.

To see why, it is necessary first to take a closer look at the problem that prompted the adoption of the zero-tolerance policy. After the report became public, UNHCR enlisted the United Nations' Office of Internal Oversight Services (OIOS) to verify the information it contained. ${ }^{203}$ After an in-depth investigation, ${ }^{204}$ the team issued a final report substantiating a handful of allegations of sexual abuse and exploitation against a UN volunteer, a UN peacekeeper, and some NGO staff members who worked in the refugee camps. Notably, the investigative team concluded that " $[\mathrm{t}]$ he evidence did not substantiate any of the cases involving regular United Nations staff members."205

In light of these findings, the zero-tolerance policy may well appear poorly targeted to address the problem. After all, the policy focuses on UN officials, making clear that acts of sexual exploitation and sexual abuse constitute serious misconduct and are "therefore grounds for serious disciplinary measures, including summary dismissal." 206 The zero-tolerance policy does address UN peacekeepers, stating that "United Nations forces conducting operations under United

\footnotetext{
${ }^{199}$ UN Secretary-General's Bulletin, Special Measures for Protection from Sexual Exploitation and Sexual Abuse, UN Doc. ST/SGB/2003/13 (Oct. 9, 2003) [hereinafter SEA Bulletin]

${ }^{200}$ See, e.g., Audrey Gillan \& Peter Moszynski, Aid Workers in Food for Child Sex Scandal, Guardian (Feb. 27, 2002); see also Rep. of the Off. of Internal Oversight Servs. on the Investigation into Sexual Exploitation of Refugees by Aid Workers in West Africa, UN Doc. A/57/465 (Oct. 11, 2002) [hereinafter OIOS West Africa Report].

${ }^{201}$ Lipson, supra note 95, at 10, 18.

202 CAR Panel Report, supra note 33, at 16.

203 OIOS West Africa Report, supra note 200, at 7.

${ }^{204}$ OIOS established an investigative team comprised professional investigators, lawyers, refugee protection and human rights specialists, translators, and a pediatric trauma specialist. Over a period of six months, the investigators observed camp activities in the three countries and conducted nearly three hundred individual interviews. Id. at 6,14 .

205 Id. at 11 .

206 SEA Bulletin, supra note 199, sec. 3.2(a).
} 
Nations command and control are prohibited from committing acts of sexual exploitation and sexual abuse ...."207 But this provision initially had limited efficacy. In 2005, following media reports that UN peacekeepers in the Democratic Republic of the Congo were sexually exploiting and abusing Congolese women and girls, then the secretary-general appointed Prince Zeid Ra'ad Zeid Al-Hussein (who would later become the High Commissioner for Human Rights) to write a comprehensive report. ${ }^{208}$ Among other things, Al-Hussein's report pointed out that the zero-tolerance policy's provision regarding peacekeepers was not legally binding: "Rules can be made binding on military members of contingents only with the agreement of and action by the troop-contributing country concerned." 209 The troop-contributing countries had not agreed to make them binding-indeed, they had not even been asked to do so.

Even taking these features of the zero-tolerance policy into account, it is possible to cast the zero-tolerance policy in a more positive light than Lipson does. The individuals who have engaged (or may in the future engage) in sexual violence and exploitation while implementing UN policies or mandates hold a range of positions within or relationships to the United Nations. From the victim's perspective, "it is immaterial whether the perpetrator was wearing a blue helmet or not. In either case, there has been a betrayal of trust by the very person who has been authorized by the UN to protect civilians." 210 But from the perspective of the United Nations, these differences do matter because the organization's legal authority and practical control over individuals varies. As a legal and bureaucratic matter, the organization cannot ignore the differences among these categories, which contribute to the complexity of the task the United Nations faces in effectively confronting sexual violence by UN-affiliated individuals.

Considering this context, then, the zero-tolerance policy might be characterized as an important and necessary first step-though one that does not supply a comprehensive solution. Adopting a policy that applies to UN officials is a sensible place to start. After all, among the individuals who may engage in sexual violence while implementing UN mandates, the United Nations has the most authority and control over its own officials. The General Assembly and the UN secretary-general are in a position to set the terms, conditions, and standards of their employment, and the secretary-general is authorized to enforce them by imposing disciplinary measures on any staff members who engage in misconduct. ${ }^{211}$ Under these circumstances, it would have been strange for the United Nations not to clarify the standards that apply to its own officials when trying to address the issue of sexual exploitation and abuse more generally.

When it comes to UN peacekeepers, the critique of the zero-tolerance policy as cosmetic or symbolic has greater force. But in the years that followed, the General Assembly and the UN Secretariat took the necessary steps to legally apply the prohibition on sexual exploitation and

207 Id., sec. 2.2 .

208 Letter Dated 24 March 2005 from the Secretary-General to the President of the General Assembly, UN Doc. A/59/710 (Mar. 24, 2005).

${ }^{209}$ Zeid Ra'ad Zeid Al-Hussein (Permanent Rep. of Jordan), A Comprehensive Strategy to Eliminate Future Sexual Exploitation and Abuse in United Nations Peacekeeping Operations, 12, UN Doc. A/59/710 (Mar. 24, 2005) [hereinafter 2005 SEA Report].

${ }^{210}$ CAR Panel Report, supra note 33, at 4.

${ }^{211}$ UN Secretary-General's Bulletin, Staff Regulations and Rules of the United Nations, Art. X, Regulation 10.1, UN Doc. ST/SGB/2017/1 (Dec. 30, 2016). 
abuse to UN peacekeepers. Within two years of Al-Hussein's report, the General Assembly had implemented his recommendation to revise the model memorandum of understanding (MOU) between the United Nation and troop-contributing countries so that it would incorporate the zero-tolerance policy. ${ }^{212}$ By 2009, the UN Department of Peacekeeping Operations reported that all existing MOUs had been amended to reflect the revised model MOU. ${ }^{213}$

Notably, at that point, the zero-tolerance policy still did not apply to troops that were not under UN command. It was only after the incidents in the Central African Republic became widely known that UN bodies focused on applying the zero-tolerance policy to non-UNcommand troops. In 2016, the General Assembly adopted a resolution endorsing uniform standards and reaffirming that "all categories of personnel in United Nations peacekeeping operation must be held to the same standard of conduct so as to preserve the image, credibility, impartiality and integrity of the United Nations . . .."214 To apply the zero-tolerance policy to non-UN-command troops, the Security Council must become involved. And in the secretary-general's 2017 report on sexual exploitation and sexual abuse, he urged the Security Council to do exactly that when drafting mandates for non-UN forces. ${ }^{215}$

To be sure, articulating a zero-tolerance policy and ensuring that it applies to all individuals involved in peace operations is only one facet of a comprehensive approach to addressing sexual violence perpetrated by UN-affiliated individuals. Many other policies and procedures (for example, those governing prevention, complaints, investigation, reporting, and victim support) need to be developed - and they also need to be implemented. But focusing on the basic step of articulating and applying the zero-tolerance policy highlights some of the complexities that the United Nations faces when it comes to establishing and carrying out a comprehensive set of policies to address sexual violence by UN-affiliated individuals. There are clear temptations to opt for symbolic fixes-but classifying the zero-tolerance policy as symbolic or genuine is difficult.

\section{Problematic Responses: Suppressing Information About Sexual Violence in the Central African Republic?}

As explained in Part II, the value of a good reputation to international organizations, combined with available tools for suppressing information, may make it tempting to suppress or conceal damaging information. Over the years, NGOs, UN officials, and academic commentators have decried the "culture of silence" that pervades the United Nations when it comes to sexual violence and other kinds of abuse and exploitation perpetrated by UN-affiliated individuals. ${ }^{216}$ Parfait Onanga-Anyanga, having replaced Babacar Gaye as the head of the UN

2122005 SEA Report, supra note 209, at 13; GA Res. 61/267B (July 24, 2007); UN GAOR, Report of the Special Committee on Peacekeeping Operations and its Working Group, General Assembly Official Records, 61st Sess., Supp. No. 19, UN Doc. A/61/19/Rev.1, Annex.

${ }^{213}$ UN Secretary-General, Special Measures for Protection from Sexual Exploitation and Sexual Abuse, para. 23, UN Doc. A/63/720 (Feb. 17, 2009).

${ }^{214}$ See GA Res. 70/286, para. 74 (June 17, 2016).

${ }^{215}$ Report of the Secretary-General, Special Measures for Protection from Sexual Exploitation and Abuse: A New Approach, at para. 61, UN Doc. A/71/818 (Feb. 28, 2017) [hereinafter 2017 SEA Report].

216 See, e.g., Geoffrey York, Failure to Act on Sex Abuse by UN Peacekeepers Undermines Missions: Dallaire, GLOBE \& MAIL (CANADA) (May 14, 2015) (quoting Roméo Dallaire, who commanded the beleaguered UN peacekeeping 
Mission in the Central African Republic, repeated over and over that the "days of silence are over" when it comes to sexual exploitation and abuse ${ }^{217}$ — suggesting that days of silence had indeed preceded. Recall too that The Guardian news article that broke the story of the allegations against the Sangaris described Anders Kompass as a whistleblower who faced disciplinary proceedings for his singular willingness to take the allegations seriously. ${ }^{218}$ Subsequent press coverage likewise referred to Kompass as a "whistleblower" who suffered retaliation after "leaking" information about the allegations against the French forces. ${ }^{219}$

A closer look reveals no indications of the starkest methods that one might imagine to hide derogatory information-shutting down investigations or shredding documents in order to keep people outside of the United Nations from learning about the allegations. But it does expose deliberate choices to leave some stones unturned and to exclude information from public reports. Perhaps more surprisingly, there are some indications that the Secretariat downplayed some exculpatory information about its handling of the allegations against the Sangaris.

\section{Investigations, public reports, and the whistleblower}

A first question is how UN officials in Bangui reacted to the initial allegations against the Sangaris. One possibility would be to simply ignore them. But, as described above, they did not. Instead, Renner Onana immediately authorized an investigation ${ }^{220}$ — though he "warned [the interviewers] about the sensitivity of this investigation and the deflagration that this investigation will create." 221 The CAR Panel Report pointed out that Onana could have done more: some of the children who were interviewed described other child victims. ${ }^{222}$ No UN officials tried to identify, speak with, or provide services to those other child victims. $^{223}$ There may be room to criticize Onana's actions-but there is no indication in the CAR Report, other UN documents, or subsequent press reports that the organization willfully blinded itself to avoid learning about the allegations.

Second, there is the issue of whether and how information about the allegations against the Sangaris was made public. In 2014, as various individuals and offices within the Secretariat learned about the allegations, two regular reports offered possible vehicles for making the public aware of the allegations. Neither clearly required information about these allegations. One

force in Rwanda during the 1994 genocide, using the phrase), at https:/www.theglobeandmail.com/news/ national/canadians-join-campaigners-calling-for-end-to-un-peacekeeper-sex-abuse/article24420285.

${ }^{217}$ Parfait Onanga-Anyanga, Opinion, How the U.N. Is Countering Child Sex Abuse by Its Troops, NewsWeEK (Mar. 30, 2016), at http://www.newsweek.com/how-un-countering-child-sex-abuse-troops-442315 ("I make one point in all my conversations, whether with our military and police or with representatives of local populations: the days of silence are over.").

${ }^{218}$ See Laville, supra note 1.

${ }^{219}$ See, e.g., Colum Lynch, Exclusive: U.N. Drops Leak Investigation into Human Rights Official in CAR Sex Scandal, FOR. POL'Y (Jan. 15, 2016), at http://foreignpolicy.com/2016/01/15/kompass-zeid-high-commissioner-sex-scandal-peacekeepers-exclusive-u-n-drops-leak-investigation-into-human-rights-official-in-car-sexscandal; Agence France-Presse, Whistleblower Who Exposed Food-for-Sex Child Sex Among Peacekeepers Resigns Over UN “Impunity," TelegrapH (June 7, 2016), at https://www.telegraph.co.uk/news/2016/06/07/whistleblowerwho-exposed-food-for-child-sex-among-peacekeepers.

${ }^{220}$ CAR Panel Report, supra note 33, at Appendix. C.1 at para. 9.

${ }^{221} \mathrm{Id}$. at Annex B, Comments of Head of the Human Rights \& Justice Section, MINUSCA, para. 9.

222 See supra notes 135-136 and accompanying text.

${ }^{223}$ CAR Panel Report, supra note 33, at 36. 
was the annual report by the secretary-general on sexual exploitation and abuse. ${ }^{224}$ But these reports — which the secretary-general had been producing since 2003- did not at that time include information about allegations against forces like the Sangaris that were not under UN command. ${ }^{225}$ The other report was the secretary-general's annual report on children and armed conflict. The secretary-general started generating these reports in 2005, following the Security Council's request that he establish a monitoring and reporting mechanism on children and armed conflict. ${ }^{226}$ The reports address six grave violations of humanitarian law, including rape and other forms of sexual violence, when committed by any party to an armed conflict, including "state armed forces, paramilitaries, [and] non-state armed groups." 227 According to the CAR Panel Report, after internal debates about whether Sangaris forces were appropriately characterized as a party to an armed conflict, the decision was made to exclude information about the allegations against the Sangaris. ${ }^{228}$ Whether to characterize peacekeepers and others tasked with implementing peace operations as parties to an armed conflict is a genuinely difficult and controversial question. ${ }^{229}$ The view that the allegations against the Sangaris do not fit the monitoring and report mechanism criteria is plausible as a legal matter. For that reason, the initial decision to exclude the Sangaris allegations does not, by itself, indicate a desire to suppress damaging information.

The publication of The Guardian story on April 29, 2015 230 marks an inflection point when it comes to the United Nations' actions and incentives to publicly release information about sexual violence allegations against various individuals implementing UN mandates. Until that point, downplaying information about such allegations might have appeared conducive to protecting the organization's reputation. But once the story broke, the risks associated with further efforts to hide information became significantly greater. ${ }^{231}$ Indeed, after the newspaper story was published, the United Nations became significantly more forthcoming about allegations of sexual violence, exploitation, and abuse in the Central African

${ }^{224}$ These reports are produced pursuant to GA Res. 57/306 (May 22, 2003).

${ }^{225}$ In June 2016, the UN General Assembly adopted a resolution that requested the secretary-general to "to include in future reports [on sexual exploitation and abuse] information on allegations of sexual exploitation and abuse by non-United Nations forces operating under a Security Council Mandate.” GA Res. 70/286, para. 82 (July 8, 2016). The 2017 report on SEA included those allegations for the first time. See 2017 SEA Report, supra note 215 .

${ }^{226}$ SC Res. 1612, paras. 2-3 (July 26, 2005).

${ }^{227}$ Office of the Special Representative of the Secretary-General for Children and Armed Conflict, Monitoring and Reporting Mechanism (MRM) on Grave Violations Against Children in Situations of Armed Conflict, Field Manual, at 15-16 (2014), available at http://www.mrmtools.org/mrm/files/ MRM_Field_5_June_2014.pdf.

${ }^{228}$ CAR Panel Report, supra note 33, at 38.

229 The question is both controversial and important because the answer, among other things, determines whether peacekeepers can be lawful targets. See, e.g., D.W. Bowett, United Nations Forces: A Legal Study 484-516 (1964); Dietrich Schindler, United Nations Forces and International Humanitarian Law, in STUDIES and Essays on International Humanitarian Law and Red Cross Principles 521 (Christopher Swinarski ed., 1984); Christopher Greenwood, Protection of Peacekeepers: The Legal Regime, 7 Duke J. Comp. \& INT'L L. 185 (1996); Brian D. Tittemore, Belligerents in Blue Helmets: Applying International Humanitarian Law to United Nations Peace Operations, 33 Stan. J. Int'L L. 61 (1997); Devon Whittle, Peacekeeping in Conflict: The Intervention Brigade, MONUSCO, and the Application for International Humanitarian Law to United Nations Forces, 46 Geo. J. INT'L L. 837 (2015).

${ }^{230}$ Laville, supra note 1.

${ }^{231}$ Daugirdas 2019, supra note 14 (identifying a similar inflection point in connection with the United Nations' response to the cholera outbreak in Haiti). 
Republic and also more generally. Most significantly, Secretary-General Ban Ki-moon commissioned the CAR Panel Report. In June 2015, the United Nations reversed course on what information belonged in the monitoring and report mechanism reports and started including allegations against both peacekeepers and non-UN command forces. ${ }^{232}$

Likewise, in the months that followed the publication of The Guardian story, the United Nations started to share more information about new allegations with the media. ${ }^{233}$ The Secretariat has since taken further steps to make at least some types of information publicly available more quickly. Most significantly, the Secretariat now makes available online "near real-time information on allegations received as well as updates to previously reported allegations, going back to 2015."234 This website includes allegations against UN officials and UN peacekeepers, both military and police, though allegations against non-UN command forces are excluded. ${ }^{235}$ At least with respect to allegations of sexual violence against these categories of actors, the United Nations has established policies to mandate disclosure.

Third, there is the apparent whistleblower-Anders Kompass, who was at the time the director of a division within the UN Office of the High Commissioner for Human Rights. Although Kompass's disclosures pre-dated The Guardian article, his story does not neatly fit the narrative of an international organization seeking to punish an official who exposed to the public evidence that his organization has engaged in wrongdoing.

According to the CAR Panel Report, on July 23, 2014, exactly one month after Palayret's interviews were completed, Kompass told the deputy representative of the French mission in Geneva about the allegations. ${ }^{236}$ The French representative asked for a copy of the interview notes, and Kompass provided them a few days later without making any modifications or redactions. ${ }^{237}$ These communications constitute the "leaking" for which Kompass was later suspended and investigated. According to subsequent press reports, "sources close to the case" said that Kompass passed the document to the French authorities "because of the UN's failure to take action to stop the abuse."238

To start, it is odd to characterize Kompass's sharing of the allegations with the French government as "leaking" because he did not make the information available to the public. According to the CAR Panel Report, some OHCHR staff believed that, by sharing the

${ }^{232}$ UN Secretary-General, Children and Armed Conflict, para. 44, UN Doc. A/69/926-S/2015/409 (June 5, 2015); UN Secretary-General, Children and Armed Conflict, para. 43, UN Doc. A/70/836-S/2016/360 (Apr. 20, 2016).

233 See supra notes 144, 149-150 (newspaper stories that rely in part on information provided by official UN sources).

${ }^{234}$ United Nations, Conduct in UN Field Missions: Sexual Exploitation and Abuse, Table of Allegations, at https://conduct.unmissions.org/table-of-allegations; see also 2017 SEA Report, supra note 215, para. 70 ("[T]he global public has long become accustomed to learning of serious social transgressions through news outlets in addition to official sources. The United Nations must responsibly and regularly make use of respected news outlets in the service of greater transparency and accountability. My Spokesperson will establish a system to ensure that appropriate facts regarding credible reports of sexual exploitation and abuse are publicly and regularly released to the media, as standard practice.").

235 United Nations, Conduct in UN Field Missions: Sexual Exploitation and Abuse, Alleged Perpetrators, at https://conduct.unmissions.org/sea-subjects.

${ }^{236}$ CAR Panel Report, supra note 33, at 65.

${ }^{237}$ Id.

${ }^{238}$ Laville, supra note 1. 
allegations in this way, Kompass was simply doing his job. ${ }^{239}$ That is also how the French government understood Kompass's communication: the French responded with a formal diplomatic note thanking him for bringing the allegations to the government's attention. ${ }^{240}$ In other words, this reaction suggests that the French government did not view Kompass as making a secret, unauthorized disclosure of adverse information about the United Nations.

In any case involving claims of whistleblower retaliation, there are competing accounts of the motivation for penalizing the employee making a disclosure. According to Kompass's boss -Al-Hussein, the High Commissioner for Human Rights- the problem was not Kompass's desire for a robust response to the allegations against the Sangaris soldiers. ${ }^{241}$ Instead, AlHussein told the CAR Panel, two aspects of Kompass's disclosure troubled him. First, he (and some other staff in OHCHR) believed that Kompass had, on more than one occasion, shared sensitive information with a member state in order to curry favor and support for a promotion. ${ }^{242}$ The second issue was that Kompass had flouted norms regarding confidentiality when he shared with the French government an unredacted copy of the notes that included names and other identifying information about the child victims and witnesses. ${ }^{243}$

Even if the response to Kompass's disclosure is not a classic case of retaliation against a whistleblower, it still serves as a cautionary tale about the consequences to UN officials of taking forceful action on the basis of ambiguous authority-even in a situation where the action in question had a "significant and positive effect," 244 that is, it prompted French authorities to launch a criminal investigation. The United Nations' internal investigation eventually cleared Kompass of all charges. ${ }^{245}$ Nevertheless, his widely publicized experience may reinforce preexisting incentives that exist for UN officials to avoid taking risks. ${ }^{246}$

\section{A twist: Downplaying exculpatory information?}

This final subsection returns to the French government's handling of the allegations during the period after Kompass shared Palayret's interview notes and before The Guardian's exposé was published-that is, between July 2014 and April 2015. As noted above, when Palayret initially shared information about the allegations with the French military in Bangui, she

${ }^{239}$ CAR Panel report, supra note 33, at 66.

${ }^{240}$ Id. at 57, n. 239 \& Appendix A, para. 26.

241 Id. at Appendix C.5, at 3.

242 Starting in the fall of 2015, Kompass was under investigation for sharing information with Morocco for these reasons. The investigation did not substantiate this claim, but some of Kompass's colleagues continued to believe that this personal agenda motivated his disclosures to both Morocco and France. Id., Appendix C.5, at 1-2; Colum Lynch, Exclusive: U.N. Drops Leak Investigation into Human Rights Official in CAR Sex Scandal, FOR. POL'Y, at http://foreignpolicy.com/2016/01/15/kompass-zeid-high-commissioner-sex-scandal-peacekeepers-exclusive-u-n-drops-leak-investigation-into-human-rights-official-in-car-sex-scandal. Ironically, Kompass was accused of trying to curry favor with the French government by sharing exactly the same information that Kompass's colleagues in Bangui viewed as radioactive.

243 See supra notes 180-182.

${ }^{244}$ CAR Panel Report, supra note 33, at 69.

245 Sandra Laville, UN Whistleblower Who Exposed Sexual Abuse by Peacekeepers is Exonerated, GUARDIAN (Jan.18, 2016), at https://www.theguardian.com/world/2016/jan/18/un-whistleblower-who-exposed-sexualabuse-by-peacekeepers-is-exonerated.

${ }^{246}$ Darrow \& Arbour, supra note 175, at 452 ("The troubling reality is that the United Nations internal incentives, accountability systems, and support structures do not generally tend to encourage courageous positions. ... To the contrary, the more discernible tendency has been toward risk aversion."). 
described their reaction in positive terms. ${ }^{247}$ Likewise, after diplomats in Geneva and New York learned of the allegations, the French government dispatched investigators to Bangui immediately and the public prosecutor's office in Paris opened a preliminary inquiry. ${ }^{248}$ After The Guardian story became public, then-President Hollande likewise took a strong stand against impunity. ${ }^{249}$

In between, though, relatively little happened. The French investigators dispatched to Bangui in August 2014 did not interview any of the children making allegations during that initial trip. ${ }^{250}$ Nor did the prosecutor's office take any apparent steps to interview possible perpetrators until after The Guardian story broke. ${ }^{251}$ The public prosecutor in Paris launched a formal investigation into the allegations on May 7, 2015, shortly after The Guardian story was published. ${ }^{252}$ The prosecutor's office suggested that the United Nations was to blame for its inactivity up to that point, explaining that the prosecutor wanted first to interview Palayret, but "the international institution refused to lift its immunity, preferring instead to respond to a written questionnaire." 253

The French prosecutor's suggestion that that the United Nations inappropriately impeded its own investigation does not withstand scrutiny, however. The United Nations does have comprehensive immunities, but those immunities did not pose an obstacle to Palayret's cooperation with the investigation. In a press conference the next day, the spokesperson for the UN secretary-general explained that the request to lift immunity was a red herring:

[T] here was no need to lift immunity because this cooperation would be done on a voluntary basis without any prejudice to the investigation ... to our immunities. ... [T] he issue of immunity, I think, is one that is not always fully grasped by those that don't cover the UN on a regular basis. The UN lifts the immunities of its staff members in a number of cases when they need to testify in front of judges, in front of courts. We do that. The immunity is not there to stand in the way of justice being served. At this point, if there's no need to lift the immunity, it's not lifted. If there is a need to lift the immunity to provide testimony before a judge or a court in a legal proceeding, it is studied. It is very often done. 254

Even more importantly, however, it is not at all clear why the prosecutor's office insisted on interviewing Palayret before proceeding with the investigation. After all, the office already had in its possession Palayret's unredacted interview notes, which included details about both the children she interviewed and about the alleged perpetrators-including information about

247 See supra note 169

248 See supra note 170; Chine Labbé, Information judiciaire sur des soldats français en Centrafrique, REUTERS FranCE (May 7, 2015), at http://fr.reuters.com/article/idFRKBN0NS1ED20150507.

249 See supra note 171.

${ }^{250}$ France 2 Envoyé spécial, supra note 169; Labbé, supra note 248.

${ }^{251}$ France 2 Envoyé spécial, supra note 169.

252 Labbé, supra note 248; Aurelien Breeden, France Opens Criminal Inquiry into Charges of Abuse by Peacekeepers in Africa, N.Y. Times (May 7, 2015).

253 Labbé, supra note 248 (translated by the author).

${ }^{254}$ UN Press Release, Daily Press Briefing by the Office of the Spokesperson for the Secretary-General (May 8, 2015), at https://www.un.org/press/en/2015/db150508.doc.htm (ellipses in original). This description accords with the United Nations' standard practices. See The Conventions on the Privileges and Immunities of the United Nations and Its Specialized Agencies: A Commentary 92-93 (August Reinisch ed., 2016). 
their names, nicknames, tattoos, piercings, and distinctive jewelry. ${ }^{255}$ The notes supplied many leads that the French investigators apparently declined to pursue until after The Guardian story broke.

To put it bluntly, the French scapegoated the United Nations for its own inaction. What is striking is that, apart from the single press conference quoted above, the United Nations did very little to protect its reputation by contradicting this narrative. Through its silence and passivity, the Secretariat seems even to have facilitated the shifting of blame from the French government to the United Nations. ${ }^{256}$ Consider the CAR Panel Report's treatment of the issue. Echoing the public prosecutor's office, the report criticized the UN legal office for asserting immunity and declared that the office's "failure to give appropriate weight to the goal of accountability unnecessarily impeded the French investigation and may have resulted in the loss of relevant evidence." 257 The report further underscored the issue in its recommendations, encouraging the United Nations to "[a]dopt an approach to immunity that presumes cooperation and active participation of UN staff in accountability processes." ${ }^{258}$ In his formal response to the CAR Report, the secretary-general did nothing to contest the characterization of immunity as an obstacle to the French investigation; instead, he wrote that he has "accepted and implemented the Panel's recommendation that the Organization adopt an approach to immunity that presumes the cooperation and active participation of United Nations staff in accountability processes." 259

Here again, a reputational lens can explain what might initially seem puzzling: the United Nations downplayed information that might have mitigated some of the significant reputational damage that the organization incurred. The key is to break out the organization's multiple audiences. By highlighting the French investigators' failure to do more with the information they had at their disposal early on, the United Nations might have avoided some damage to its own reputation among the public. But doing so would simultaneously impair the organization's relationship with a powerful P-5 member. Whether by virtue of a calculated decision or not, the United Nations took the bullet.

The United Nations, like other international organizations, makes choices about what information to make available and what information to keep under wraps. In general, international organizations possess some important tools that allow them to suppress adverse information. And, in some instances, individual UN officials have some incentives to suppress adverse information. However, as the specific incidents reviewed in this section illustrate, the desire to protect the organization's reputation in the eyes of the public is only part of the story.

\footnotetext{
255 France 2 Envoyé spécial, supra note 169.

256 This is another example of the way that silence helps to shape reputations. See supra note 49.

257 CAR Panel Report, supra note 33, at 56.

258 Id. at 95.

259 Report of the Secretary General, Combating Sexual Exploitation and Abuse, para. 74, UN Doc. A/71/97 (June 23, 2016).
} 


\section{E. The Missing Dimension of Reputation: The United Nations'Reputation for Compliance with Legal Obligations}

Over and over again, UN secretaries-general have condemned sexual violence by UN peacekeepers and others tasked with implementing UN mandates, describing it as an urgent problem the organization must solve. ${ }^{260}$ Notably, however, inside the United Nations - and to a large degree outside the United Nations as well—-this discussion has not been framed in legal terms. On the one hand, this framing is not surprising: the United Nations' acts and omissions regarding sexual violence do not constitute a clear violation of international law for which the organization is responsible. On the other hand, the absence of a strong claim that the United Nations has violated international law — and the fact that its reputation for compliance with international law is not threatened - may help explain why reputational damage has not prompted a more dramatic response within the organization and from member states.

International organizations (like states) are responsible for violations of international law if two criteria are met: the organization's conduct-that is, its acts or omissions-(1) must be attributable to the organization, and (2) must constitute a violation of international law. ${ }^{261}$ The International Law Commission's Draft Articles on the Responsibility of International Organizations (Draft Articles) specify the conduct that is attributable to international organizations. Such conduct includes the conduct of organs or agents of the organization; the conduct of organs and agents of a state that are placed at the disposal of an international organization, if the organization exercises effective control over that conduct; and conduct that is not otherwise attributable but is accepted or adopted by the organization as its own. ${ }^{262}$

Applying this framework to the sexual abuses by the French Sangaris is straightforward. There is little doubt that the allegations against the Sangaris describe serious violations of international law. But as a matter of international responsibility, their conduct is attributable to France, not to the United Nations. ${ }^{263}$ As noted above, although they were in the Central African Republic pursuant to a UN mandate, the French troops were not under UN command. ${ }^{264}$ The commentary to the Draft Articles explains that the articles do not expressly assert-although they do imply_ " that conduct of military forces of States . . . is not attributable to the United Nations when the Security Council authorizes States . . . to take necessary measures outside a chain of command linking those forces to the United Nations."265

\footnotetext{
${ }^{260}$ For a sampling, see UN Press Release, Sexual Exploitation "Utterly Immoral," Completely at Odds with United Nations Mission, Says Secretary-General to New York Conference, UN Doc. SG/SM/10776-PKO/156 (Dec. 4, 2006), at https://www.un.org/press/en/2006/sgsm10776.doc.htm (Kofi Annan); Full Transcript of the Secretary-General's Remarks to Press on the Central African Republic, Aug. 12, 2015, at https://www.un.org/sg/ en/content/sg/press-encounter/2015-08-12/full-transcript-secretary-generals-remarks-press-central (Ban Kimoon); Combating "Scourge" of Sexual Abuse Allegations Remains "Key" UN Priority, as 54 New Allegations Emerge, UN News (May 1, 2018), at https://news.un.org/en/story/2018/05/1008712.

${ }^{261}$ Draft Articles on the Responsibility of International Organizations with Commentaries, Art. 4, in Report of the International Law Commission on Its Sixty-third Session, UN Doc. A/66/10 (2011) [hereinafter Draft Articles].

${ }^{262}$ Id. Arts. 6, 7, 9

${ }^{263}$ Draft Articles on the Responsibility of States for Internationally Wrongful Acts, with Commentaries, Arts. 4 7, UN Doc. A/56/10 (2001).

${ }^{264}$ See supra notes $125-126$ and accompanying text.

${ }^{265}$ Draft Articles, supra note 261, ch. II, cmt. (5).
} 
The analysis for UN peacekeepers participating in MINUSCA is a little less straightforward, but the result is the same: acts of sexual violence committed by the peacekeepers are not attributable to the United Nations. The key provision of the Draft Articles provides:

The conduct of an organ of a State or an organ or agent of an international organization that is placed at the disposal of another international organization shall be considered under international law an act of the latter organization if the organization exercises effective control over that conduct. ${ }^{266}$

In other words, attribution turns on the "factual control that is exercised over the specific conduct taken by the organ or agent placed at the receiving organization's disposal." 267

As Tom Dannenbaum has persuasively argued, under the legal regime that currently governs the relationship between the United Nations and troop-contributing countries, it is the troop-contributing country that exercises "effective control" when UN peacekeepers perpetrate sexual violence. ${ }^{268}$ To support this conclusion, Dannenbaum carefully considers both the formal legal relationship between the UN and the practical dynamics between them. Under the legal arrangements that govern peacekeeping, the United Nations is limited to exercising "operational control," which falls considerably short of "full command" and allocates decision making over key issues, including discipline and training, to national officials. ${ }^{269}$ As a practical matter, the United Nations' control is limited even further: overt disobedience of UN commanders is not unheard of, and troop-contributing states exercise significant influence over the formulation and execution of peacekeeping missions. ${ }^{270}$ Troop contributions are voluntary, and the "threat of withdrawal can be used as an ultimatum to resolve disputes over the direction of a mission or the specific situation of the national contingent." 271

These conclusions do not end the inquiry about the legality of the United Nations' conduct, however. The United Nations could also incur international responsibility if it has violated international law by failing to do enough to prevent sexual violence to aid victims or to hold individual perpetrators accountable. As noted above, although UN secretaries-general have, on multiple occasions, insisted that the organization must do better along these dimensions, they have never suggested that the United Nations has a legal obligation to do so. The CAR Panel's report suggests that this view carries over to lower-level officials. Indeed, when it came to the allegations against the Sangaris, some UN officials went further. Not only did they lack a legal obligation to address the allegations against the Sangaris-but, they said, they believed they lacked the legal authority to do so. ${ }^{272}$

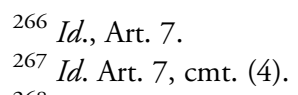

${ }^{268}$ Tom Dannenbaum, Translating the Standard of Effective Control into a System of Effective Accountability, 51 HarV. INT'L L.J. 113, 163 (2010)

${ }^{269} I d$. at $142-48$.

${ }^{270} \mathrm{Id}$. at $148-50$.

${ }^{271} \mathrm{Id}$. at 150; see also supra note 192 (describing such threats in relation to allegations of sexual violence).

272 CAR Panel Report, supra note 33, at 4 ("In the course of the Review it became clear that in the eyes of many UN staff, the human rights framework does not apply to allegations of sexual violence by peacekeepers. As a result, where there is an allegation that a peacekeeper not operating under UN command has sexually assaulted a civilian (and the SEA Policies do not apply), some UN staff take the view that the UN has no obligation, or indeed authority, to address the reported sexual violence."). 
Some external actors have argued that the United Nations does indeed have legal obligations when it comes to preventing and responding to allegations of sexual violence by UN peacekeepers or other soldiers under UN command. The CAR Panel Report suggested as much. ${ }^{273}$ Separately, at least one NGO has argued that the United Nations has a due diligence obligation "to ensure that civilians in the host State are protected from criminal acts perpetrated by troop-contributing countries"-and incurs international responsibility when that obligation is breached. ${ }^{274}$

These arguments are not implausible, but they are not a slam-dunk either. There are two possible sources of such obligations. One is the UN Charter, which provides that the United Nations "shall promote . . . universal respect for, and observance of, human rights and fundamental freedoms for all without distinction as to race, sex, language, or religion." ${ }^{275}$ The difficulty here is translating this general language into specific rules governing the organization's efforts to prevent and respond to acts of sexual violence. The other possible source of these obligations is customary international law. But here there is even more room for contestation-about whether customary international law binds international organizations at all, which human rights norms have customary law status, and how norms developed primarily to address the relationship between governments and individuals apply to international organizations. ${ }^{276}$

In sum, the United Nations' legal obligations have played a muted role to date in the organization's handling of sexual violence by the Sangaris and UN peacekeepers in the Central African Republic and elsewhere. This state of affairs is not set in stone, however. It is possible for international law-and by extension the United Nations' reputation for complying with it - to feature more prominently. A variety of mechanisms are available through which the United Nations could clarify its international obligations, including treaties and unilateral statements. ${ }^{277}$ The next Part considers these, as well as other possible mechanisms, to make reputation a more effective disciplinarian of international organizations.

\footnotetext{
${ }^{273} I d$. at 38 ("When looking at the [UN's] human rights policy framework, it is clear that the UN has the responsibility to address acts of sexual violence as human rights violations and potential violations of international humanitarian law and international criminal law. This includes the obligation to investigate the incidents, report both internally and publicly on the violations, protect the victims and work to hold the perpetrators accountable.").

${ }^{274}$ REDRESS, Sexual Exploitation and Abuse in Peacekeeping Operations Report 37 (2017), available at https:// redress.org/wp-content/uploads/2017/08/REDRESS-peacekeeping-report-English.pdf.

275 UN Charter Art. 55.

${ }^{276}$ Compare Kristina Daugirdas, How and Why International Law Binds International Organizations, 57 HaRV. INT'L L.J. 325 (2016) (arguing that customary international law and general principles do bind international organizations) with Jan Klabbers, Sources of International Organizations' Law: Reflections on Accountability, in THE Oxford Handbook on the Sources of International Law 987 (Samantha Besson \& Jean d'Aspremont eds., 2017) (arguing only some such rules bind international organizations).

277 Nuclear Tests (Austl. v. Fr.), 1974 ICJ Rep. 253, 267 (Dec. 20) (holding that unilateral engagements can create binding international law commitments).
} 


\section{Can Reputation Be a Good-or a Better-Disciplinarian?}

\section{A. Two General Lessons}

\section{Convergence About What Constitutes a Good Reputation}

As this Article has shown, a key limitation of reputation as a disciplinarian is that reputations have multiple dimensions and organizations have multiple audiences. These multiplicities seriously complicate the pursuit of a "good" reputation. The implication is that reputation will be most effective as a disciplinarian when there is agreement within an international organization and among its various audiences about what constitutes a good reputation. Put another way, one key take-away from this analysis is that reputation will be most effective when the desire to maintain a good reputation does not tug organizations in conflicting directions.

For example, various reputational multiplicities converge (at least to some degree) when it comes to sound financial management-and more specifically avoiding corruption and abuse of organizational resources for private benefit. This issue received considerable attention in the early 2000s in connection with the United Nations' oil-for-food program. That program was designed to mitigate the effects on the civilian population of the comprehensive economic sanctions that the Security Council had imposed on Iraq by allowing the Iraqi government to sell some oil to purchase basic necessities. After allegations of abuses and mismanagement mounted in the press, former Secretary-General Kofi Annan appointed former Federal Research Bank Chair Paul Volcker to head an independent inquiry committee. That committee issued an interim report that cited "major failures to abide by UN procurement and contracting procedures in the oil-for-food program, and harshly criticized the program's former director." 278 Annan understood the threat the scandal posed to the organization and its reputation, saying: "For an organization like the UN, any hint of corruption and misbehaviour and that sort of disrespect for rules is harmful, and is dangerous and we cannot dismiss it, and we do take it seriously." 279 Volcker's later report found "no personal misconduct by the secretary-general" but nevertheless "faulted him for failing to prevent poor management and corruption in the program." 280 Annan resisted calls from some quarters for his resignation and completed his second term as secretary-general-but the incident continues to be prominently associated with his tenure. ${ }^{281}$

\footnotetext{
278 John R. Crook, Oil-for-Food Audits Released to U.S. Congress; Widened Congressional Probes of United Nations, 99 AJIL 495, 496 (2005).

${ }^{279}$ United Nations Secretary-General, Unofficial Transcript of the Secretary-General's Press Encounter upon Arrival to UNHQ, Feb. 4, 2005, at https://static.un.org/sg/en/content/sg/press-encounter/2005-02-04/unofficial-transcript-secretary-generals-press-encounter-upon; see also supra note 26 and accompanying text.

${ }^{280}$ John R. Crook, Further U.S. Reactions to Abuses in UN Oil-for-Food Program; U.S. Criminal Charges Against UN Officials, Others, 99 AJIL 904, 905 (2005). Volcker also faulted UN member states, particularly those on the Security Council, for turning a blind eye to extensive smuggling of Iraqi oil. Id.

281 See, e.g., Kofi Annan, U.N. Secretary General and Nobel Peace Prize Laureate, Dies at 80, Obituary, WaSH. PosT. (Aug. 18, 2018), at https://www.washingtonpost.com/local/obituaries/kofi-annan-former-un-secretarygeneral-dies-at-80/2018/08/18/12eed974-a2ce-11e8-83d2-70203b8d7b44_story.html (devoting several paragraphs to describing the oil-for-food scandal).
} 
In recent years, international organizations have adopted more robust rules and regulations concerning the proper control of funds and have developed independent audit mechanisms to enforce them. ${ }^{282}$ A recent incident shows that—in at least some cases-international organizations have strong incentives to follow through when serious violations are identified. Recently, a UN audit found that Erik Solheim, who had been the executive director of the UN Environment Program (UNEP), had repeatedly violated internal rules regarding travel and had incurred half a million dollars in travel expenses in less than two years. ${ }^{283}$ According to the press, the audit cited the "reputation risk" these violations posed to UNEP, especially in light of its work fighting climate change. ${ }^{284}$ Several European member states publicly threatened to halt funding for UNEP until the issues regarding Solheim were resolved. ${ }^{285}$ Finally, Solheim, a Norwegian national, lost the support of his own government. ${ }^{286}$ Under these circumstances, asking for Solheim's resignation was an easy call for Secretary-General Guterres. ${ }^{287}$ The action required to bolster the organization's reputation for morality and legality aligned with the action demanded by key member states.

All that said, examples of genuine convergence about what constitutes a good reputationand what steps are necessary to maintain it - are likely to be rather rare. Even when it comes to preventing and punishing corruption and financial mismanagement, disagreements are likely to emerge-and when they do, reputation's efficacy as a disciplinarian will diminish. Thus, even if an international organization's audiences agree that certain egregious forms of corruption or self-dealing are inappropriate and unacceptable, that agreement may dissipate when it comes to other examples. As Michael Johnston has put it, corruption is a "deeply normative concern": while corruption can be usefully defined as "the abuse of public roles or resources for private benefit," every one of those key terms_-"abuse," "public," "private," and "benefit"-is subject to some degree of ambiguity and contestation in many societies. ${ }^{288}$ The UN secretary-general and his counterparts in other organizations may have a difficult time firing officials who retain significant support among some member states-or when the seriousness of their wrongdoing is disputed. (Indeed, even when it came to oil-for-food, the reaction within member states varied quite significantly based on ideology and partisanship. ${ }^{289}$ )

282 Jacob Katz Cogan, Financing and Budgets, in The Oxford Handbook of International Organizations 903, 917 (Jacob Katz Cogan, Ian Hurd \& Ian Johnstone eds., 2016).

${ }^{283}$ Damian Carrington, UN Environment Chief Resigns After Frequent Flying Revelations, Guardian (Nov. 20, 2018); Somini Sengupta, U.N. Environment Envoy Quits After Audit of Expenses, N.Y. Times (Nov. 20, 2018).

${ }^{284}$ Carrington, supra note 283.

285 Id.

${ }^{286}$ Nina Berglund, Ousted Solheim Fires Back at UN, NewsinEngLish.no (Nov. 28, 2018), at https://www. newsinenglish.no/2018/11/28/ousted-solheim-fires-back-at-un (describing an article about Solheim's resignation published in Aftenposten, a leading newspaper published in Norway).

${ }^{287}$ Id.; Carrington, supra note 283.

${ }^{288}$ Michael Johnston, Syndromes of Corruption 10-13 (2005).

289 Compare Ian Williams, The True UN Scandal: Who Pocketed the \$10 Billion for Iraq?, 23 WORLD POL. J. 27 (2007) (suggesting that the conservative media made a mountain out of a molehill) with KENNETH ANDERSON, LIVING WITH THE UN 157 (2012) (citing the "widespread belief at the United Nations and among its elite constituents that it did nothing, or at any rate very little, wrong in the oil-for-food scandal, and this was a put-up job by the United States and the Bush administration"). 


\section{A Cautionary Note}

A second lesson that emerges from this Article is that simply turning up the volume-seeking to make organizational reputation a more pressing concern-is not necessarily going to be helpful because efforts to preserve a good reputation are not always going to be salutary. Because reputations depend on others' perceptions, an instruction to pay more attention to reputation will not always have beneficial results. In particular, it can prompt efforts to tend to appearances instead of addressing the underlying reality, and thus create incentives to adopt only symbolic or cosmetic measures, or to suppress damaging information.

There is yet another reason why a greater focus on reputation might be problematic: it may make international organizations more risk averse. (Such risk aversion with respect to reputation is hardly unique to international organizations. ${ }^{290}$ ) Focusing more on reputation may mean focusing more on the possibility of failure-and it is not clear that doing so across-theboard would enhance decision making by international organizations, which are often tasked with trying to manage especially risky and dangerous situations.

To take just one example, Michael Barnett and Martha Finnemore scrutinized the work of the UN Secretariat in the months leading up to what is still considered one of the organization's biggest failures - its lack of forceful action to prevent genocide in Rwanda. Between April 6 and July 19, 1994, roughly 800,000 Rwandans were killed. ${ }^{291}$ At the time, there was a small peacekeeping force of about 2,500 troops, known as UNAMIR, to help implement a previously negotiated ceasefire in the country. ${ }^{292}$ Instead of ramping up its efforts, the Security Council wound them down, voting on April 21-as the genocide was underway - to reduce UNAMIR to 250 troops and to restrict its mandate to supporting the negotiation of a new ceasefire. ${ }^{293}$ Barnett and Finnemore focus their attention not on the members of the Security Council, but rather on the UN Secretariat, observing that, "[d] uring these first critical weeks the Secretariat did little to discourage the emerging consensus in the Security Council in favor of withdrawal. It failed to recommend an intervention to protect civilians or even to lay one on the table for serious consideration." 294

Barnett and Finnemore do not frame their analysis in terms of reputation. They focus instead on bureaucratic pathologies, and in particular the Secretariat's undue privileging of rules and procedures at the expense of the United Nations' overarching purposes. But their narrative account of decision making within the Secretariat can also be framed in reputational terms as an illustration about how concern about reputation can make organizations

\footnotetext{
${ }^{290}$ Scholars of domestic bureaucracies have already noticed the ways that reputational concerns may reinforce organizational tendencies towards risk aversion. CARPENTER, supra note 13, at 67-68 (suggesting that regulators in national governments will be reluctant to make decisions that are costly to reverse - and observing more generally that "familiarity and predictability are all the more important to reputation-conscious regulators"); id. at 56-57 (explaining how some agencies have responded to reputational damage by seeking to diminish expectations about what they can be expected to accomplish). Private firms are sometimes also risk averse when it comes to their reputations. VOGEL, supra note 12, at 73 (noting that firms with highly visible brands - and in particular those that have been criticized by activists in the past-are highly risk-averse and engage in corporate social responsibility in order to avoid being singled out among their competitors).

${ }^{291}$ Report of the Independent Inquiry into the Actions of the United Nations During the 1994 Genocide in Rwanda, at 3, UN Doc. S/1999/1257 (Dec. 15, 1999).

292 SC Res. 872 (Oct. 5, 1993).

293 SC Res. 912 (Apr. 21, 1994).

${ }^{294}$ Michael Barnett \& Martha Finnemore, Rules for the World 121 (2004).
} 
excessively risk averse. In particular, Barnett and Finnemore describe an organization still reeling from a disaster in Somalia and desperate to avoid another failure. ${ }^{295}$ As they explain, this fear colored the way the organization interpreted the information it was receiving from officials on the ground in Rwanda and the scope of the peacekeeping missions' mandate. ${ }^{296}$

In short, more concern about reputation is not always better. As a result, it may not be a good idea to instruct international civil servants to strive (more) to protect the reputation of the organization that employs them. ${ }^{297}$ Another implication, addressed in more detail below, is that more transparency is not necessarily better. Disclosures of information can raise the reputational stakes for organizations, but not always in productive ways. A more nuanced analysis is needed - one that takes reputational dynamics into account. The next section considers what insights a reputational lens can offer for shaping UN policies related to sexual violence.

\section{B. (Re-)Orienting Reputational Concerns}

As Part III's case study of the Central African Republic demonstrates, when it comes to the issue of preventing and responding to sexual violence, reputational concerns pulled the United Nations in different directions. Among other things, the Secretariat had to contend with member states who were quite concerned about how the organization's acts or omissions would reflect on their own reputations. ${ }^{298}$ This dynamic raises the question: is there a way to reorient reputational concerns to mitigate this tension between the organization and its member states? One promising reorientation is to focus on the way that states respond to allegations. Indeed, there already seems to be some support for this framing among UN member states and within the secretariat. As Isobel Coleman, former U.S. ambassador to the United Nations for Management and Reform put it, allegations should not be the source of dishonor for troop-contributing countries. Instead, " $\mathrm{t}]$ he dishonor is not prosecuting credible allegations of sexual exploitation and abuse to restore integrity to peacekeeping." 299

To see why such a reorientation would be helpful, consider the secretary-general's annual reports on sexual exploitation and abuse. The General Assembly has required the publication of these reports since $2003 .{ }^{300}$ In general, information disclosure can heighten the salience of reputation in general - as well as the salience of particular dimensions of reputation. Thus, for example, the California Transparency in Supply Chains Act requires companies to disclose their efforts (or lack thereof) to ensure that their supply chains are free from slavery and human trafficking. ${ }^{301}$ At least in theory, this law will encourage firms to take steps to supervise their supply chains, in part by making it easier for activists and NGOs to "exert reputational pressure as part of a campaign for better sourcing and human rights practices among

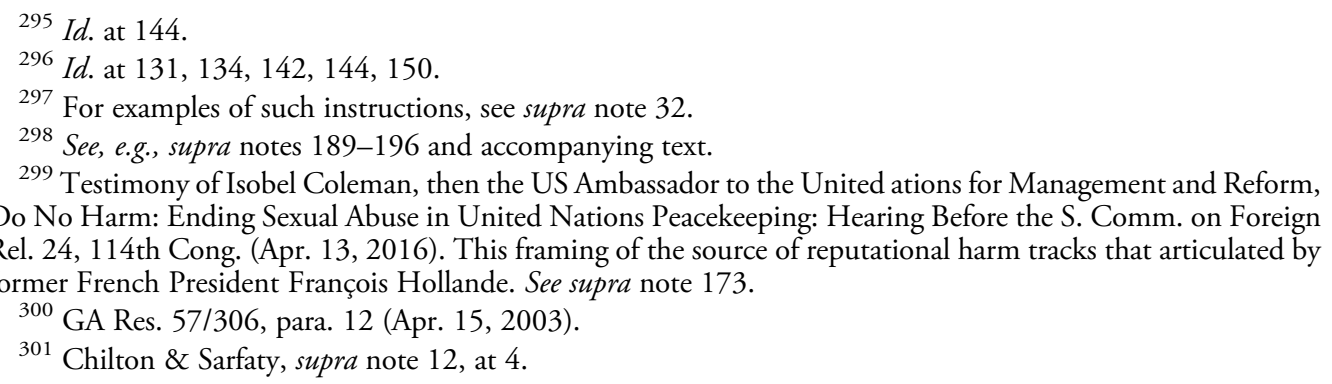


companies."302 The secretary-general's annual reports on sexual exploitation and abuse constitute the most salient information disclosures that the organization is currently making. The reports also help sustain attention by prompting discussion among UN member states ${ }^{303}$ and by generating press stories ${ }^{304}$ at regular intervals.

It is worth carefully considering the content of these reports. Among other things, they tally the nature and number of allegations made against UN officials and peacekeepers every year. This does not necessarily communicate useful information to the United Nations' audiences about how they ought to evaluate the organization's efforts because the number of allegations does not bear any consistent or reliable relationship to the actual size of the problem. Underreporting is a significant problem. Moreover, the degree of underreporting may be inversely related to the quality of the United Nations' response to allegations of sexual violence and exploitation. That is, victims are less likely to bother making a report if they believe that doing so is pointless or if they fear being blamed or otherwise penalized by reporting such allegations. ${ }^{305}$ A higher number of incidents may reflect a bigger problem on the ground, but it may also reflect a better response on the part of the organization. In its annual reports, the United Nations has chosen the positive interpretation both when allegations have decreased (crediting the effectiveness of its preventing efforts) and when they have increased (crediting victims' increased willingness to come forward). ${ }^{306}$

Separately, relying on the total number of allegations as a measure of success or failure of the organization's efforts to combat sexual violence may create a temptation to reduce the recorded number of allegations in pathological ways. Measuring success in this way might cause the organization or individual officials to discourage victims from making reports, or to decline to follow up on information that may lead to allegations. This temptation may be all the greater because reporting allegations and the nationalities of the alleged perpetrators puts the organization in a confrontational posture with troop-contributing countries, who fear that publicizing that information will dishonor their troops and damage their national reputations. ${ }^{307}$

Secretary-General Guterres has already taken some promising steps to support such a reorientation. In his very first report to the General Assembly, Guterres included a new annexone that highlighted the best practices that member states have adopted to prevent and respond to sexual exploitation and abuse. The annex elaborated on those practices and

302 Id. at 5.

303 Cf. Ndulo, supra note 7, at 132-33 ("These reports [issued pursuant to Resolution 1325] are debated in the Security Council and provide an opportunity to assess and reflect on the progress that is being made in combating sexual crimes and sexual exploitation during conflicts and in post-conflict areas and have provided opportunities to deal with sexual violence against women.").

304 See, e.g., Associated Press, U.N. Report Describes Sex Abuse Allegations About Peacekeeping Missions, N.Y. Times (Mar. 3, 2016), at https:/www.nytimes.com/2016/03/04/world/un-report-describes-sex-abuse-allegations-about-peacekeeping-missions.html.

305 See generally Grubb \& Turner, supra note 176; Machiko Kanetake, Whose Zero Tolerance Counts? Reassessing a Zero Tolerance Policy Against Sexual Exploitation and Abuse by UN Peacekeepers, 17 InT'L PeACEKEEPING 200, 208-09 (2010).

${ }^{306}$ Kate Grady, Sex, Statistics, Peacekeepers and Power: UN Data on Sexual Exploitation and Abuse and the Quest for Legal Reform, 79 Modern L. ReV. 931, 941-43 (2016).

307 See supra notes 190-192 and accompanying text (observing that both international organizations and states have reputational concerns). 
identified by name the states that designed and implemented them. ${ }^{308}$ Building on this effort to allow states to burnish their reputations by strengthening their responses to sexual exploitation and abuse, Guterres also invited current and former heads of state (or government) to join a "Circle of Leadership on the prevention of and response to sexual exploitation and abuse in United Nations operations." 309 One of the participants' first acts was to issue a collective statement affirming their personal commitment as global leaders to support efforts to combat sexual exploitation and abuse across the United Nations system. ${ }^{310}$ Currently seventy-two sitting and former heads of state are members of this Circle. ${ }^{311}$

Guterres has also developed a new kind of "voluntary compact" that troop-contributing countries may enter into with the United Nations. These compacts have three overarching objectives:

(a) to clearly define the specific commitments of both the Organization and the Member States in advancing our joint efforts to combat sexual exploitation and abuse;

(b) to accelerate the timely implementation of agreed measures; and

(c) to strengthen coordination and coherence in our collective response in cases involving civilian and uniformed personnel alike. ${ }^{312}$

So far, one hundred states have signed the voluntary compact with the secretary-general. ${ }^{313}$ Like the efforts described above, these voluntary compacts offer a means to reorient attention (and, by extension, reputation) to focus on responses to rather than the existence of allegations.

Shifting attention to responses rather than allegations may also helpfully alter the dynamics surrounding sexual violence by framing the issue as a common problem that the organization and troop-contributing countries are working together to solve. As the Central African Republic case study illustrates, UN officials struggle when they must confront member states that are suppliers of key organizational resources. This dynamic makes it important to consider how such confrontations might be defused. There are a number of areas where the Secretariat might provide useful technical assistance to troop-contributing countries-for example by promulgating model policies regarding sexual violence or by reviewing national legislation to ensure that acts prohibited by the UN zero-tolerance policy are also penalized pursuant to domestic law.

While the Secretariat has taken some positive steps, they are not sufficient on their own. For starters, it is important to sustain these efforts over time. Guterres's 2018 report omitted all annexes, directing readers to a website for detailed information about allegations, and reporting simply that he encourages member states to continue to "share their experiences

\footnotetext{
3082017 SEA Report, supra note 215.

${ }^{309}$ United Nations, Preventing Sexual Exploitation and Abuse; Circle of Leadership, at https:/www.un.org/ preventing-sexual-exploitation-and-abuse/content/circle-leadership.

$310 \mathrm{Id}$.

${ }^{311} I d$.

3122017 SEA Report, supra note 215, para. 58

${ }^{313}$ Member State Signatories to the Voluntary Compact with the Secretary-General of the United Nations on the Commitment to Eliminate Sexual Exploitation and Abuse (Oct. 5, 2018), available at https://www.un.org/ preventing-sexual-exploitation-and-abuse/sites/www.un.org.preventing-sexual-exploitation-and-abuse/files/compact_countries_list_05_october_2018.pdf.
} 
and best practices." 314 Omitting the best-practices annex is a mistake. The Circle of Leadership complements_-but does not substitute for-praising specific practices implemented by specific states, especially because participation in the Circle does not require taking any particular concrete steps.

In addition, a reputational lens highlights a key challenge for the voluntary compacts: ensuring that they are not merely a symbolic or cosmetic response but instead actually influence conduct on the ground. What, if anything, happens if participating states or the United Nations fail to implement these commitments? The discussion in Parts I and II suggests that it will be quite difficult for the UN Secretariat to confront troop-contributing countries about such failures. In light of the predictable pressure that the UN officials will face to overlook noncompliance with the voluntary compact, the establishment of an independent monitoring mechanism is worth exploring. States may bristle at the prospect, but the Secretariat may have some tools at its disposal to entice participation. Perhaps continued participation in the Circle of Leadership could depend on accepting such a monitoring mechanism.

Another possibility would be to convert the voluntary compact into a legally binding agreement - and thereby raise the reputational stakes by putting on the line the reputations of both participating states and the United Nations or complying with international law. Of course, even if the United Nations were willing to take that step, troop-contributing countries may not be. If that is the case, the United Nations could announce a unilateral legal commitment regarding its handling of legal obligations. Such a commitment could be freestanding or framed as elaborations of the organization's preexisting obligations under the UN Charter or customary international law. Coupling this step with an independent monitoring mechanism would be even more significant. ${ }^{315}$

Finally, it would also be helpful to resolve conflicts within the organization with respect to what constitutes an effective response to allegations of sexual violence. Recall the discussion of the UN Bangui office's interactions with the French investigators in August 2015-and the apparent tension between the human rights officials' focus on protecting victims and goal of facilitating the French criminal investigation. ${ }^{316}$ The question of how to advance prosecutions while also protecting child victims and witnesses and respecting their rights to privacy and confidentiality raises some genuinely difficult issues. Advocates, scholars, and international organization officials have wrestled with these issues in other contexts, including with respect to prosecutions in the International Criminal Court. ${ }^{317}$ In response to a recommendation from the CAR Panel report, ${ }^{318}$ the Secretariat reports progress in developing a "uniform policy on balancing the disclosure of information to national authorities with

\footnotetext{
${ }^{314}$ Report of the Secretary-General, Special Measures for Protection from Sexual Exploitation and Abuse: A New Approach para 72, UN Doc. A/72/751 (Feb. 15, 2018) [hereinafter 2018 SEA Report].

${ }^{315}$ While this step is likely to be a tough sell, the Human Rights Advisory Panel, which was established to hear claims that the UN interim administration in Kosovo had violated international human rights law, is an important precedent. The Human Rights Advisory Panel, at http://www.unmikonline.org/hrap/Eng/Pages/default.aspx.

316 See supra notes 180-182 and accompanying text.

317 See, e.g., Chelsea Swanson, Elizabeth Devos, Chloe Ricke \& Andy Shin, Expert Workshop Session: Child Witnesses: Testimony, Evidence, and Witness Protection, 43 GA. J. InT'L \& Comp. L. 649 (2015).

${ }^{318}$ CAR Panel Report, supra note 33, at 84 (recommending that a working group "review[] UN policies dealing with confidentiality in order to establish a proper balance between informed consent, protection, and accountability").
} 
principles of confidentiality" when handling allegations of sexual exploitation and abuse. ${ }^{319}$ The secretary-general intends to formalize and publish this policy as a bulletin before the end of $2018 .^{320}$ The bulletin will merit close scrutiny to ascertain the likelihood that it has successfully resolved the tension between protection and prosecution - and has helped to align views within OHCHR and the UN Secretariat about what constitutes a reputation for effectiveness.

The more general point is that a reputational lens can usefully inform policy discussions. Some of the observations above are widely applicable — for example, that more transparency will not always improve reputational dynamics or lead to better outcomes. Separately, a reputational lens can help to identify policies that will be difficult to implement robustly because doing so requires individuals or organizations to provoke confrontations with key audience members, or to trade off one valued dimension of reputation against another. Policy design should be sensitive to what is easy and hard for individuals or organizations to do-and should seek to make desirable outcomes easier to achieve.

\section{Conclusion}

Hobbes observed that: "Reputation of power is power."321 Sometimes reality and appearances converge; sometimes efforts to cultivate a particular kind of reputation drive a wedge between reality and appearances. Both have causal force. In giving an account of when and how international organizations' secretariats are motivated to protect reputation, this Article emphasizes that reputation is not always a salutary force. This feature of reputation makes it all the more important to understand how reputational dynamics work. This Article has set out to do that, recognizing that international organizations operate in an ecosystem made up of other entities - most notably states - that are eager to protect their own reputations.

Scholarship has long recognized that international organizations can influence the reputation of states, especially by collecting, distilling, and communicating information about their implementation of various international agreements. ${ }^{322}$ This Article has shifted the focus to international organizations - or, to be more precise, their secretariats—as key actors that have their own reputations. Like any other entity or individual, international organizations operate under constraints. Their member states can make it easier or harder for secretariats to cultivate any given facet of the organization's reputation. A key question for future scholarship is understanding when and why they do so.

3192018 SEA Report, supra note 314, para. 38.

${ }^{320} \mathrm{Id}$.

${ }^{321}$ Hobbes, Leviathan, at ch. 10, para. 10 (1651).

322 CHAYEs \& CHAYEs, supra note 78, at 124-28. 